\title{
The influence of sleep and sleep loss upon food intake and metabolism
}

\author{
Cibele Aparecida Crispim ${ }^{1,2}$, Ioná Zalcman ${ }^{1,2}$, Murilo Dáttilo ${ }^{1}$, Heloisa Guarita Padilha ${ }^{1}$, Ben Edwards ${ }^{3}$, \\ Jim Waterhouse ${ }^{3}$, Sérgio Tufik ${ }^{1}$ and Marco Túlio de Mello ${ }^{1}$ \\ ${ }^{1}$ Psychobiology Department, Federal University of Sao Paulo, Sao Paulo, Brazil \\ ${ }^{2}$ Postgraduation Program in Nutrition, Federal University of Sao Paulo, Sao Paulo, Brazil \\ ${ }^{3}$ Research Institute for Sport and Exercise Sciences, Liverpool John Moores University, Liverpool, UK
}

\begin{abstract}
The present review investigates the role of sleep and its alteration in triggering metabolic disorders. The reduction of the amount of time sleeping has become an endemic condition in modern society and the current literature has found important associations between sleep loss and alterations in nutritional and metabolic aspects. Studies suggest that individuals who sleep less have a higher probability of becoming obese. It can be related to the increase of ghrelin and decrease of leptin levels, generating an increase of appetite and hunger. Sleep loss has been closely associated with problems in glucose metabolism and a higher risk for the development of insulin resistance and diabetes, and this disturbance may reflect decreased efficacy of the negativefeedback regulation of the hypothalamic-pituitary-adrenal axis. The period of sleep is also associated with an increase of blood lipid concentrations, which can be intensified under conditions of reduced sleep time, leading to disorders in fat metabolism. Based on a review of the literature, we conclude that sleep loss represents an important risk factor for weight gain, insulin resistance, type 2 diabetes and dyslipidaemia. Therefore, an adequate sleep pattern is fundamental for the nutritional balance of the body and should be encouraged by professionals in the area.
\end{abstract}

\section{Sleep loss: Food intake: Obesity: Appetite: Diabetes}

\section{Introduction}

A reduction of sleep time has become common in recent years, guided by the demands and opportunities of modern society ${ }^{1}$. Over the last 40 years, self-reported sleep duration has decreased by $1 \cdot 5-2 \mathrm{~h}$ in the USA ${ }^{2,3}$. The proportion of young adults with a period of sleep shorter than $7 \mathrm{~h}$ per $\mathrm{d}$ has increased from $15.6 \%$ in 1960 to $37 \cdot 1 \%$ in $2001-2^{2,3}$.

Recent studies show that the alteration in sleep time can influence various aspects associated with the nutritional and metabolic balance of the body, such as the control of body mass ${ }^{4-7}$ and the controls of food intake ${ }^{8-10}$, glycaemic levels ${ }^{1,11,12}$ and of the levels of cholesterol and $\mathrm{TAG}^{13-15}$.

Numerous studies have used different methodologies to understand the effects of sleep loss. Sleep deprivation can be total, when no sleep is allowed, or partial, when the retiring time is delayed or the rising time is advanced. In addition, deprivation can last for one or more nights. Results might depend upon the exact nature of the deprivation that is used. Some studies have used shift workers, for example, who might sleep less than day workers, under $5 \mathrm{~h}$ on working days $^{16}$. These members of the population have been the main focus of scientific work considering the relationship between sleep and nutrition. Not only might such decreased hours of sleep modify eating behaviour significantly ${ }^{14,17-22}$ but also it has been known for some time that the eating habits of night workers during the night shift are altered ${ }^{23,24}$.

Individuals that sleep less, including shift workers, have been associated in the longer term with a higher propensity for the development of nutritional problems ${ }^{25,26}$, such as obesity and altered metabolism of food ${ }^{14,17-22,24,27}$, dyslipidaemias $^{25,28}$ and diabetes ${ }^{12,29-31}$. In laboratory studies of healthy young adults submitted to recurrent partial sleep restriction, marked alterations in metabolism, including decreased glucose tolerance and insulin sensitivity $^{32}$ and altered metabolism of food ${ }^{33}$, have been demonstrated.

Given the need for a better understanding of the nutritional problems resulting from alterations in sleep patterns, the present article discusses the influence of sleep on nutritional and metabolic parameters.

\footnotetext{
Abbreviations: GH, growth hormone; HPA, hypothalamic-pituitary-adrenal; LPL, lipoprotein lipase; REM, rapid eye movement; SWS, slow-wave sleep; TSH, thyroid-stimulating hormone.

* Corresponding author: Professor Marco Túlio de Mello, fax +55 115572 0177, email tmello@psicobio.epm.br
} 


\section{Obesity and sleep}

Landmark studies by Rechtschaffen et al. ${ }^{34}$ reported that rats submitted to total sleep deprivation (by the disk-overwater method) markedly increased food intake but, nevertheless, lost weight. Many other studies have confirmed these results ${ }^{35-40}$. Recently, however, Martins et al. ${ }^{41}$ introduced different procedures to allow accurate estimation of food spillage before, during, and after $120 \mathrm{~h}$ of sleep deprivation. Their main finding was that, once corrected for spillage, food intake was not significantly increased during sleep deprivation, even though weight loss did occur during the sleep-deprivation period.

In human subjects, recent studies have pointed to a possible involvement of changed sleep hours in altered energy balance of the body and to alterations in the sleep pattern as a contributory factor to increased obesity ${ }^{1,27,42}$. Many recent studies correlate the short duration of sleep with the increase in the BMI, in adults ${ }^{4,6,7,43-45}$, children $^{46-48}$ and adolescents ${ }^{49-51}$. In a prospective single-age cohort study with 496 young adults, Hasler et al. $^{44}$ showed an association between short sleep duration and obesity and a negative association between sleep duration and BMI. These associations persisted after controlling for a variety of potentially confounding variables. Reilly et al. $^{47}$ found, in 8234 children aged 7 years, that sleep duration in the children when aged 30 months was independently associated with the prevalence of obesity at the age of 7 years. Children showing the lowest two quartiles of sleep duration $(<10.5 \mathrm{~h}$ and $10 \cdot 5-10.9 \mathrm{~h}$, respectively) were more likely to be obese at age 7 than children in the highest quartile $(>12 \mathrm{~h})$.

However, although data from prospective studies and supporting this link are emerging, most of the studies showing an association between short sleeps and obesity have been cross-sectional and do not prove causality. In an attempt to understand better the effect of sleep loss on food intake in man, studies have used models of shift work or jet lag (alterations resulting from rapid crossing of time zones), both of which are situations that alter the sleep pattern and are also associated with alterations in the pattern of food intake ${ }^{14,17-22,52}$. Some studies have reported that obesity tends to occur more frequently in association with shift work than with daytime-only work ${ }^{14,18,53-56}$. During night work $^{24,57}$ and after a time-zone transition ${ }^{24,58}$, there might be additional problems due to the lack of palatable food ${ }^{59}$. Altered eating habits are a source of concern in night workers, who tend to 'nibble' their way through crisps and chocolate bars during the night shift rather than eat a healthy and substantial meal in the middle of it $^{60-62}$. Waterhouse et al. ${ }^{63}$ analysed the transient changes in the pattern of food intake following a simulated time-zone transition. Subjects showed significant changes in their pattern of food intake. The distribution of daytime meals was significantly affected on the first post-shift day, with a redistribution of the times that the main, hot meals were eaten.

Even though the mechanisms involved in changed eating habits are not completely understood, it is known that alterations in the sleep-wake schedule affect intracellular circadian clocks - molecular mechanisms that enable the cell, tissue or organism to anticipate diurnal variations in the environment. The environment (of cells and tissues) may include circulating levels of nutrients (for example, glucose, fatty acids and TAG) and various hormones (for example, insulin, leptin, ghrelin, glucocorticoids). As such, alterations in the timing mechanism are likely to induce nutritional changes that may potentiate disrupted metabolism $^{64}$ and influence appetite, satiety and, therefore, food intake $^{33}$. It is believed also that problems in adjustment of the biological clock, so impairing the duration and quality of sleep, can also modify food intake $25,58,65$.

Therefore, we will approach more precisely the mechanisms by which the sleep loss can lead to the increase of food intake and obesity.

\section{The role of leptin and ghrelin in the control of food intake and sleep}

Eating and sleeping are two kinds of behaviour that are essential for the survival of man and higher animals. Whereas it is obvious that these two processes cannot occur at exactly the same time, there appear to be common regulators of both phenomena ${ }^{66}$. With the identification of ghrelin as the endogenous ligand of the growth hormone $(\mathrm{GH})$ secretagogue receptor ${ }^{67}$, a new endogenous regulator of food intake and, possibly, also of sleep was found. Later, Bodosi et al. $^{68}$ described a relationship between sleep, feeding and ghrelin and their antagonist in energy balance, leptin.

From these findings, many studies have clearly indicated that the reduction in total sleep time is associated with two parallel endocrine behaviours that can significantly alter food intake: the reduction of the anorexigenic hormone leptin $7,69-71$ and the increase of the orexigenic hormone ghrelin ${ }^{7,33,68}$. In individuals who sleep less, this combination of changes results in increased hunger and food intake $^{33}$. In an experiment carried out by Spiegel et al. ${ }^{33}$, sleep deprivation in men was associated with an increase of $28 \%$ in ghrelin levels, a reduction of $18 \%$ in the leptin levels and increases of $24 \%$ in hunger and $23 \%$ in appetite (Fig. 1).

Leptin is a protein composed of 167 amino acids, and it is produced mainly by the adipose tissue ${ }^{72}$. Leptin provides the regulating centre in the brain with information about energy balance, and its release is associated with the promotion of satiety ${ }^{73-80}$. Elevated leptin levels at times of metabolic excess activate an anorexigenic pathway, the peptide precursor pro-opiomelanocortin (POMC) and cocaine- and amphetamine-regulated transcript peptide (CART), and reduce activity in orexigenic pathways, neuropeptide Y (NPY) and agouti-related peptide (AgRP). Low leptin levels, occurring at times of nutrient deficit, result in a reduction of inhibitory influences on NPY/AgRP neurons, a lack of activation of POMC/CART-containing neurons and an overall increase in orexigenic signalling ${ }^{81,82}$ (see Fig. 2).

Recent studies with animals have suggested that leptin might participate in the regulation of sleep, systematically reducing rapid eye movement (REM) sleep and influencing non-REM sleep ${ }^{83}$. Other work has postulated a direct influence of leptin release on sleep, since the levels of this hormone are higher during sleep than when awake ${ }^{84}$. Some 
(A)

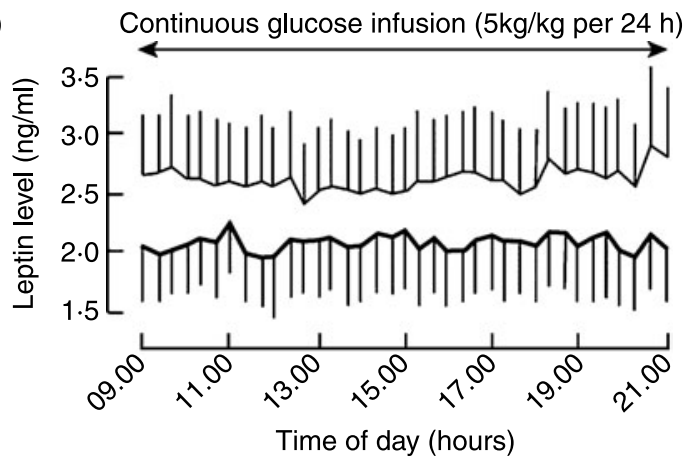

(B)

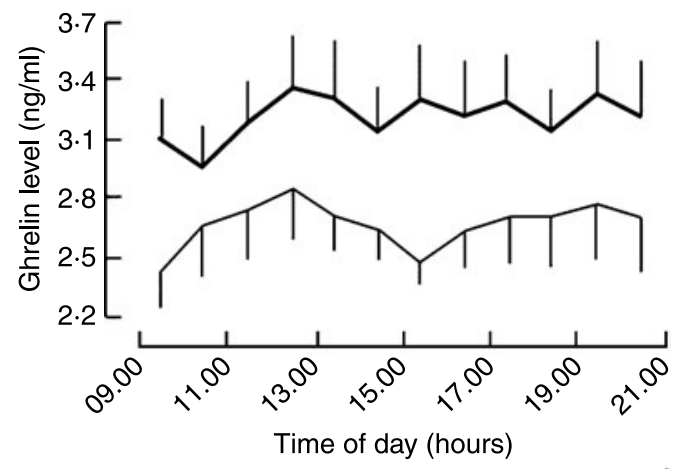

(C)

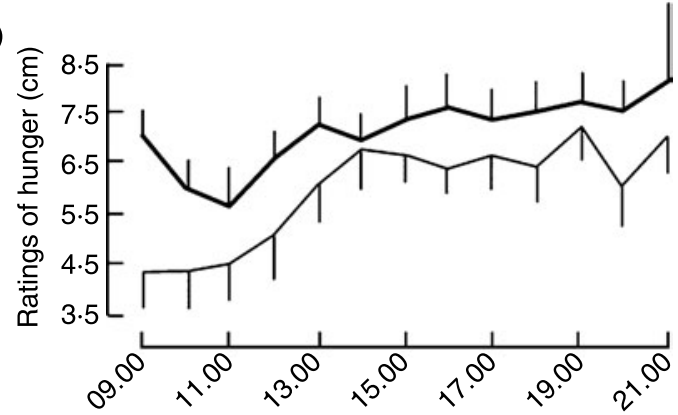

(D)

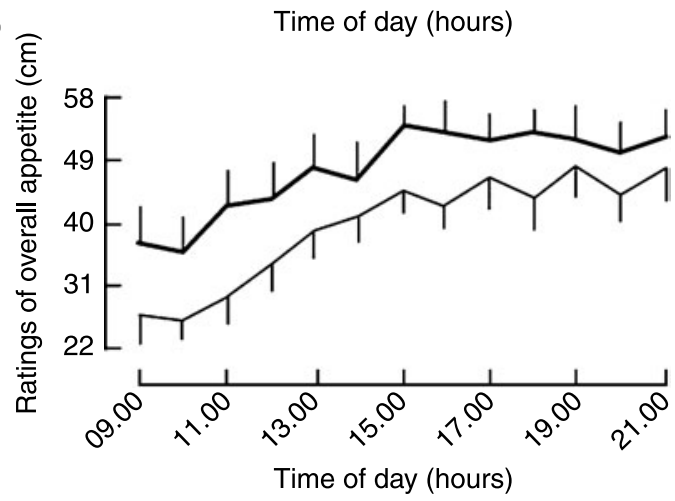

Fig. 1. Effect of sleep duration on daytime leptin levels (A), ghrelin levels (B), hunger (C) and appetite (D). (A) Daytime (09.00 to 21.00 hours) profiles of leptin after $2 \mathrm{~d}$ with $4 \mathrm{~h}$ in bed $(-)$ or $2 \mathrm{~d}$ with $10 \mathrm{~h}$ in bed (-). Mean leptin levels were $18 \%$ lower when sleep was restricted. (B) Daytime (09.00 to 21.00 hours) profiles of ghrelin from nine of the twelve participants after $2 \mathrm{~d}$ with $4 \mathrm{~h}$ in bed or $2 \mathrm{~d}$ with $10 \mathrm{~h}$ in bed. Mean ghrelin levels were $28 \%$ higher in the afternoon and early evening (12.00 to 21.00 hours) when sleep was restricted. (C) Ratings of hunger $(0-10 \mathrm{~cm}$ visual analogue scale) and (D) overall appetite $(0-70 \mathrm{~cm}$ visual analogue scale) after $2 \mathrm{~d}$ with $4 \mathrm{~h}$ in bed or $2 \mathrm{~d}$ with $10 \mathrm{~h}$ in bed. When sleep was restricted, ratings of hunger and overall appetite increased by 24 and $23 \%$, respectively. Values are means, with their standard errors represented by vertical bars. (From Spiegel et al..$^{71}$; used with permission from the Annals of Internal Medicine.)

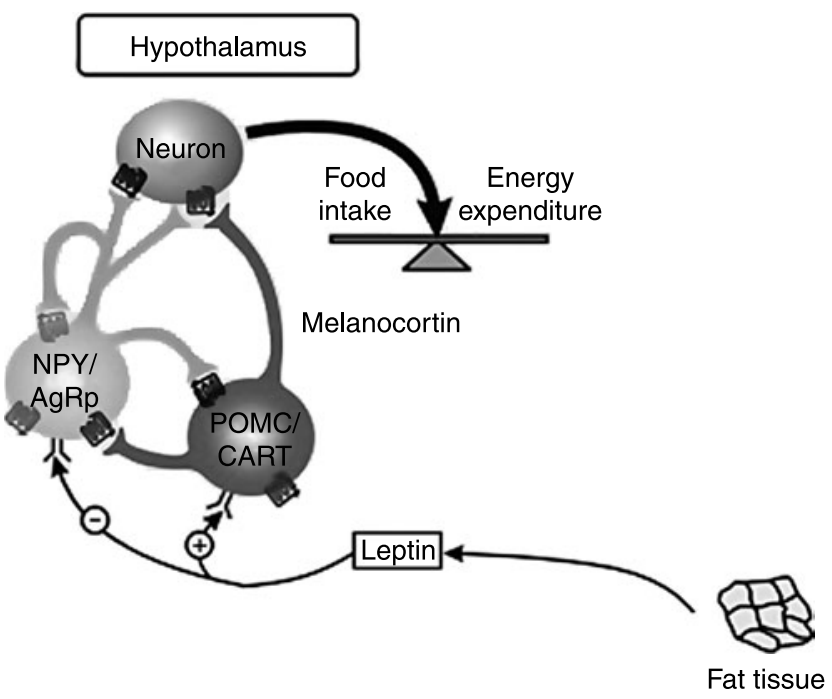

Fig. 2. Central control of food intake. Leptin stimulates proopiomelanocortin/cocaine- and amphetamine-regulated transcript peptide (POMC/CART) neurons and inhibits neuropeptide Y (NPY) and agouti-related peptide (AgRP) neurons. The result of these opposing actions is the stimulation of food intake and energy expenditure. (Adapted from Gale et al. ${ }^{229}$.)

evidence suggests that this nocturnal increase is partly a response to the intake of food that took place during the day $^{85}$. It is believed, however, that sleep per se can affect the regulation of leptin, since studies have shown that the elevation observed during sleep persists in subjects receiving continuous enteral nutrition, even when sleep occurs during the daytime $e^{71,84}$.

Evidence from other laboratory studies has shown that both chronic, partial sleep deprivation ${ }^{70}$ and acute sleep deprivation $^{69}$ might cause a reduction in the serum concentration of leptin. Spiegel et al. ${ }^{71}$ evaluated the pattern of leptin secretion in eleven male individuals subjected to a shortened sleep time $(4 \mathrm{~h})$ for six nights. Mean and maximum values of leptin were lower (by 19 and $26 \%$, respectively) during sleep restriction, compared with the same individuals when they had normal sleep $(8 \mathrm{~h})$, suggesting that sleep plays an important role in leptin secretion. Sleep restriction seems to change the capacity of leptin to respond to the body's energy balance and to produce the satiety signal when the energy needs have been adequately met ${ }^{71}$. Also, Taheri et al. ${ }^{7}$ observed, in a crosssectional study carried out with 1024 volunteers, that short sleep was associated with low leptin levels, with a decrease of $15.5 \%$ predicted for habitual sleeps of $5 v .8 \mathrm{~h}$. Chaput et al. $^{86}$ found a cross-sectional association between short sleep duration and leptin levels in a sample of 323 men and 417 women aged $21-64$ years. When compared with adults reporting $7-8 \mathrm{~h}$ of sleep per $\mathrm{d}$, and after adjustment for age, sex, and physical activity level, the adjusted OR for overweight or obesity was $1.38(95 \%$ CI $0.89,2.10)$ for those with $9-10 \mathrm{~h}$ of sleep and 1.69 (95\% CI $1.15,2.39)$ for those with $5-6 \mathrm{~h}$. However, all of these significant differences disappeared after statistical adjustment for plasma leptin levels. 
An impact of sleep duration on leptin levels could involve several mechanisms. Considering that leptin release is inhibited by the sympathetic nervous system ${ }^{87}$, another possibility is that sleep restriction results in a reduction in leptin levels due to increased sympathetic activity $^{71}$. Alterations in the regulation of cortisol and sympatho-vagal balance, the two most important neurobiological markers of stress, were clear when individuals were studied for $6 \mathrm{~d}$ of sleep restriction ${ }^{71}$. A negative association between changes in leptin levels and cortisol during sleep restriction is well documented in the literature, possibly indicating a suppressive effect of leptin on the hypothalamic-pituitary-adrenal (HPA) axis $^{88-90}$.

A parallelism between the diurnal and pulsatile variations in thyroid-stimulating hormone (TSH) and leptin levels has been reported in healthy young adults ${ }^{91}$. Spiegel et al. ${ }^{71}$ observed a positive association between $24 \mathrm{~h}$ variations in leptin and TSH after sleep restriction, which provides compelling evidence for a role for leptin in the physiological regulation of the thyrotropic axis. Evidence suggests that TRH neurons may be regulated by leptin ${ }^{90}$, and a stimulatory effect of leptin on TSH release has been suggested in $\operatorname{man}^{91-93}$ and shown in rodents. In contrast, many other studies have reported negative findings in the role of physiological concentrations of thyroid hormones on leptin regulation ${ }^{71,94,95}$.

It has been suggested that the reduction in leptin levels after sleep restriction might be an adaptation to increased energy needs, due to the increase in wake time ${ }^{71}$. Studies involving accurate measurements of energy balance in individuals submitted to chronic partial sleep loss are necessary, to rule out the possibility that the state of sleep restriction entails a significant increase in energy expenditure.

A close relationship between leptin and ghrelin, another hormone influenced by sleep, has been described. Ghrelin is a peptide composed of twenty-eight amino acids, produced mainly by the endocrine glands of the stomach ${ }^{67}$ and duodenum ${ }^{67}$, and by a number of brain structures ${ }^{96}$. This hormone increases in periods of fasting ${ }^{97}$, triggering the sensation of hunger ${ }^{97-99}$ in the arcuate nucleus ${ }^{100}$, stimulating gastrointestinal motility ${ }^{101}$ and promoting the deposition of lipids ${ }^{102}$. The arcuate nucleus is involved in the central control of food intake ${ }^{103}$, and ghrelin is the only substance that is found endogenously in mammals and that increases hunger and appetite when administered to human subjects ${ }^{104-109}$. This hormone contributes to preprandial hunger ${ }^{110}$ and plasma concentrations of ghrelin are inversely correlated with the amount of food ingested $^{68}$. Ghrelin is thought to be significantly involved in the neuroendocrine network that regulates energy balance in at least two ways. First, it acts as a peripheral hormone from the stomach that, along with other signals such as insulin or leptin, informs the central energy balance control when energy stores diminish, and also increases orexigenic drive and decreases energy expenditure. Its second involvement is as a hypothalamic neuropeptide, expressed in a previously unidentified population of neurons adjacent to the third ventricle and between the ventromedial hypothalamus, the dorsal hypothalamus, the paraventricular nucleus, and the arcuate nucleus. Efferents of ghrelin-expressing neurons project to key circuits involved in the regulation of central energy balance and may offset the activity of orexigenic neuropeptide Y/Agouti-related protein with anorectic pro-opiomelanocortin neurons and so modulate the output of the efferent pathway ${ }^{97}$.

Current evidence indicates that ghrelin is also a sleeppromoting factor $^{11}$, inducing slow-wave sleep (SWS) and the nocturnal secretion of $\mathrm{GH}^{112}$. It is well documented that there is an increase in the levels of ghrelin during sleep, followed by a decrease in the morning, some hours before breakfast. The cause of this profile remains to be clarified, since it is anomalous that the levels of a hormone that stimulates hunger are increased during sleep. It has been suggested that ghrelin might produce other metabolic and endocrine functions that remain to be ascertained ${ }^{112}$.

As in the case of leptin, sleep seems to influence the pattern of ghrelin secretion, since high levels of this hormone follow the curtailment of sleep in human subjects $^{33}$. Spiegel et al. ${ }^{33}$ showed that the curtailment of sleep (to $4 \mathrm{~h}$ ) in twelve healthy men for a period of $2 \mathrm{~d}$ was associated with an increase of almost $28 \%$ in the diurnal levels of ghrelin. Bodosi et al. ${ }^{68}$, in a study with rats, analysed plasma and hypothalamic concentrations of ghrelin before and after sleep deprivation. They observed that levels of hypothalamic ghrelin changed during and after sleep deprivation, increasing during sleep deprivation and decreasing afterwards to levels below baseline. Plasma ghrelin, on the other hand, showed increased levels both during $^{71}$ and after sleep deprivation ${ }^{111}$. Based on this evidence, it has been postulated that high levels of ghrelin in response to sleep deprivation might be a normal response of the body to a greater need for energy intake, as a result of the longer time the individual has remained awake. This hypothesis requires further investigation ${ }^{33}$. Therefore, high ghrelin levels can contribute to an increase of hunger and food intake during sleep loss.

These differences in leptin and ghrelin are likely to increase appetite, possibly explaining the increased BMI observed in individuals with short sleep duration ${ }^{7}$. The current literature indicates that the decrease of leptin and increase of ghrelin levels are considered to be the main factors that trigger the increase of hunger when the sleep pattern is altered ${ }^{33}$. Fig. 3 shows how sleep deprivation might change the pattern of ghrelin and leptin and energy balance.

Sleep deprivation seems to increase not only appetite but also the preference for foods containing more energy ${ }^{7,113}$. Spiegel et al. $^{33}$ showed that the appetite for energy-rich nutrients with high carbohydrate content, including sweets, salty snacks and starchy foods, increased by 33-45\%; by contrast, appetite for fruits, vegetables and high-protein nutrients was less affected. Lennernas et al. ${ }^{114}$ observed a great preference for the intake of 'fast food' and energy-rich snacks during the nocturnal working hours in night workers. The preference for such foods is a source of great concern since, in addition to presenting a hormone pattern that predisposes to an increased energy intake ${ }^{33}$, individuals with sleep loss (common in night workers) tend to meet this need with foods of low nutritional quality ${ }^{115-119}$. 


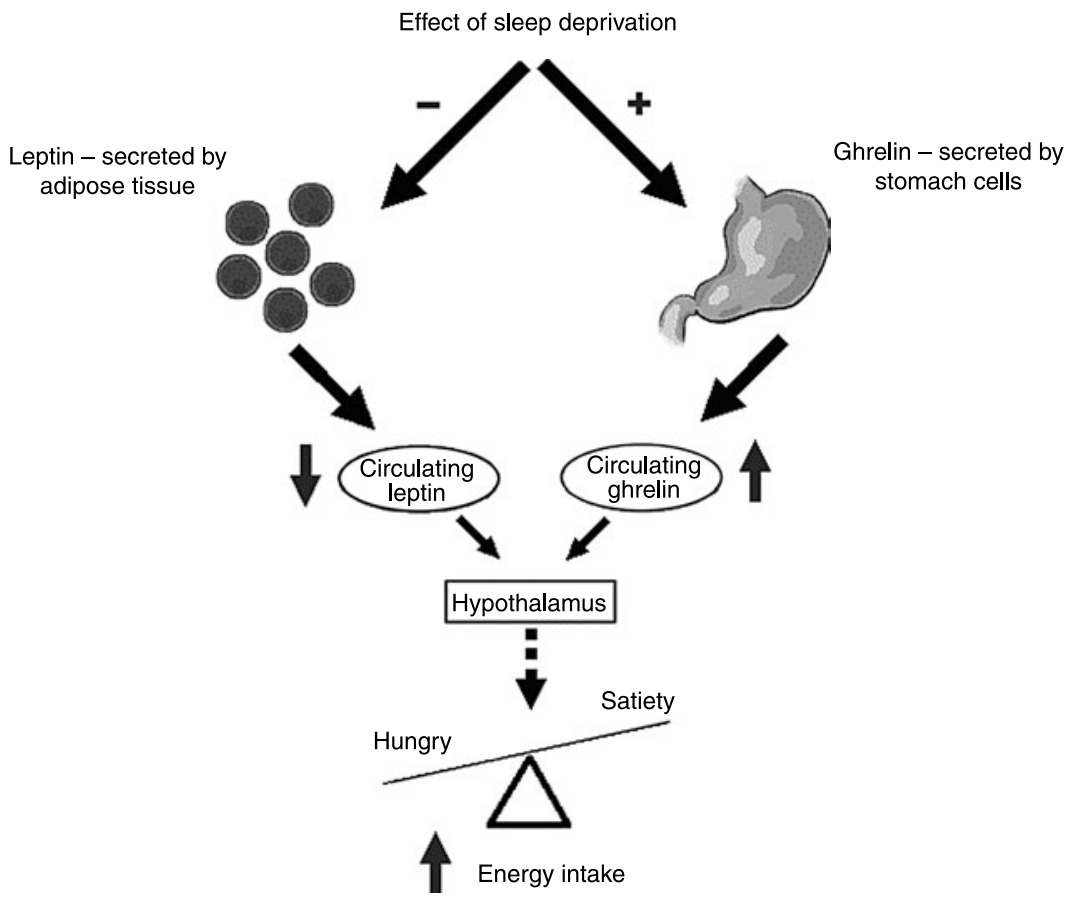

Fig. 3. Changes in the pattern of ghrelin and leptin release and energy balance produced by sleep deprivation.

This altered food intake can result from inadequate eating facilities during the night shift but, whatever its cause, it increases the risks of obesity ${ }^{26}$, dyslipidaemias ${ }^{28}$ and $\mathrm{CVD}^{115-119}$.

Sleep duration might represent a major risk factor for the development of weight gain and one that can be modified fairly easily. Unfortunately, most studies that describe hormonal and behavioural changes capable of increasing food intake have been acute interventions, and so it has not been possible to establish what would be their long-term effects. Indeed, there are many other neuropeptides that have stronger effects on food intake, and which have not been measured in sleep-loss studies. Even so, the new studies should lead to a better understanding of the role of sleep in the mechanisms that control hunger and satiety. Also, it is suggested that new studies, to measure the effect of sleep-promoting interventions on appetite and body weight, are required. Even so, the current findings suggest that changes in the levels of leptin and ghrelin, due to sleep curtailment, cause changes in food intake. That is, sleep duration can be added to the environmental factors that are prevalent in our society and that contribute to weight gain and obesity. It might be that a better night's sleep will become a goal in future attempts to combat obesity.

\section{Sleep and energy expenditure}

Sleep duration may alter the balance between energy intake and energy expenditure. With regard to energy expenditure, excessive daytime sleepiness and fatigue, resulting from sleep loss (tiredness without increased sleep propensity), have been associated with obesity and have a significant impact on individual wellbeing and public safety ${ }^{120}$.
Taheri ${ }^{121}$ stated that excessive daytime fatigue and sleepiness could contribute to reduced daytime physical activity, which many believe is a major contributor to the current obesity pandemic. Knutson ${ }^{50}$ found that about $40 \%$ of 12-16 year olds reported waking up tired; this could have a serious adverse effect on daily physical activity. Additionally, physical activity has a beneficial effect on sleep, suggesting a negative synergy between poor sleep and low physical activity.

Gupta et $a l^{49}$ studied a tri-ethnic cross-section sample of male and female adolescents, aged 11-16 years (Heartfelt Study). Data obtained from $24 \mathrm{~h}$ wrist actigraphy showed that obese adolescents experienced less sleep than nonobese adolescents $(P<0.01)$. For each hour of lost sleep, the odds of obesity increased by $80 \%$. Sleep disturbance was not directly related to obesity in the sample, but influenced physical activity levels $(P<0.01)$. Daytime physical activity diminished by $3 \%$ for every hour increase in sleep disturbance. Other studies, measuring energy expenditure in both sexes, at different ages and following sleep loss, are needed to understand better these relationships ${ }^{71,87}$.

\section{Influence of sleep on glucose metabolism}

In man, the homeostatic control of plasma glucose results in a strictly controlled balance between the distribution of glucose (originating in the liver in the post-absorptive state or from the intestine in the postprandial state) and the use of glucose by the tissues such as muscles, adipose tissue and the brain. This control prevents the development of hypoglycaemia or hyperglycaemia ${ }^{1,122}$. 
In order to investigate differences in glucose control during sleep and waking periods, a number of recent studies have measured glucose levels of individuals in both states $^{123}$. In normal subjects during an overnight sleep, blood levels of glucose remain stable or fall only minimally despite the extended fast ${ }^{122}$. By comparison, in subjects awake and fasting in a recumbent position during the daytime period, and in the absence of any physical activity, glucose levels fall by an average of $0.5-1.0 \mathrm{~mm}$ (i.e. $100-$ $200 \mathrm{mg} / \mathrm{l})$ over a $12 \mathrm{~h}$ period $^{122}$. Thus, a number of mechanisms must operate during nocturnal sleep to maintain stable glucose levels during the fasting period ${ }^{1}$.

Glucose homeostasis is critically dependent on the ability of pancreatic $\beta$-cells to release insulin both acutely (i.e. the acute insulin response to glucose, $\beta$-cell responsiveness) and in a sustained fashion, and on the ability of insulin to inhibit hepatic glucose production and promote glucose disposal by peripheral tissues (i.e. insulin sensitivity). Reduced insulin sensitivity, or insulin resistance, occurs when higher levels of insulin are needed to reduce blood glucose levels after the administration of a given amount of exogenous glucose ${ }^{1}$. Insulin resistance can lead to a marked decrease in glucose tolerance (reflected in higher plasma glucose levels). It is well established that insulin sensitivity, insulin resistance and glucose tolerance vary across the $24 \mathrm{~h}$ cycle and can be influenced by a lack of sleep ${ }^{122}$.

Recent studies have described a significant impairment in glucose control in individuals who have alterations in their sleep pattern ${ }^{1,32,124}$; these subjects are more susceptible to the onset of insulin resistance ${ }^{1,32}$ and type 2 diabetes ${ }^{1,32,125}$. Therefore, it is appropriate to address the mechanisms involved in the impaired glucose metabolism by disruption of the sleep-wake rhythm.

\section{Glucose metabolism during sleep}

Studies of nocturnal glucose tolerance during sleep determined by the balance of insulin secretion and insulin action - have used intravenous glucose infusion at a constant rate, or continuous enteral nutrition, and have sampled glucose and insulin without waking the subjects ${ }^{126-128}$.

Van Cauter et al. ${ }^{11}$ evaluated glucose and insulin secretion rates in a group of eight normal young men (aged 20-27 years) during constant glucose infusion, including an $8 \mathrm{~h}$ period of nocturnal sleep. During nocturnal sleep, levels of glucose and insulin secretion increased by $31 \pm 5$ and $60 \pm 11 \%$, respectively, and returned to baseline in the morning. During the first half of the sleep period, the increase in plasma glucose was followed by a $50 \%$ increase in insulin secretion. Under these experimental conditions, the major underlying cause of the glucose increase is decreased glucose utilisation ${ }^{11}$. The profiles of peripheral glucose and insulin concentrations observed in this study confirmed and extended the findings of previous studies, which had shown decreased glucose tolerance in the evening as compared with the morning ${ }^{129-133}$.

It is estimated that about two-thirds of the fall in glucose utilisation during early sleep is due to a decrease in brain glucose metabolism ${ }^{134}$, which is related to the predominance of SWS and associated with a $30-40 \%$ reduction in cerebral glucose metabolism relative to waking values. The remainder of the fall in glucose uptake is thought to reflect decreased peripheral utilisation. Diminished muscle tone during sleep and rapid anti-insulin-like effects of the sleeponset $\mathrm{GH}$ pulse ${ }^{135}$ are both likely to contribute to this decrease in peripheral glucose uptake. During the latter part of the night, glucose tolerance begins to improve, and glucose levels progressively decrease toward morning values, reflecting an increase in glucose uptake. This increase in glucose uptake is partially due to the increases in wakefulness and REM stages ${ }^{136}$. Indeed, glucose utilisation during REM sleep and waking is higher than during nonREM sleep ${ }^{134,137-140}$. Finally, the latter part of the night appears also to be associated with increased insulin sensitivity $^{11,141}$.

\section{Glucose metabolism during sleep loss}

Some evidence has indicated that diabetes is more likely to occur in individuals who experience sleep loss. In a longitudinal study over a 10 -year period, Suwazono et al. ${ }^{142}$ investigated the effect of alternating shifts on the onset of diabetes mellitus in Japanese workers ( $n$ 3203) compared with day-shift workers ( $n$ 2426). The OR for the development of diabetes mellitus in the alternating-shift group compared with the day-shift group was 1.35 (95\% CI $1.05,1.75)$, indicating that alternating shifts are an independent risk factor for the onset of diabetes mellitus. Morikawa et al. ${ }^{143}$ analysed the risk of diabetes mellitus in 2860 men in a factory in Japan over the course of 8 years. They found a significantly increased risk of diabetes mellitus for the two-shift, but not three-shift, system, using white-collar workers as a reference group. More specific studies have examined the relationship between sleep duration and diabetes. Trenell et al. ${ }^{144}$ found the same U-shaped relationship between sleep duration and the incidence of type 2 diabetes $^{29,145}$, independent of confounding variables. Analysis of cross-section data from the Sleep Heart Health Study also revealed that reduced sleep duration was associated with an increased prevalence of type 2 diabetes and insulin resistance, after controlling for sleep-disordered breathing ${ }^{12}$, a condition that may also independently influence glucose control ${ }^{146,147}$.

Several studies have shown major changes in glucose tolerance under conditions of sleep restriction or deprivation $^{1,32,122,148-150}$. In a laboratory study, Spiegel et al. ${ }^{32}$ analysed the glucose tolerance (measured by an intravenous bolus of glucose; $300 \mathrm{mg} / \mathrm{kg}$ body mass) in eleven young men after time in bed had been restricted to $4 \mathrm{~h}$ per night for six nights. The authors compared the sleep-debt condition with measurements taken at the end of a sleep-recovery period (fully rested condition) when participants had been allowed $12 \mathrm{~h}$ in bed per night for six nights. They observed that glucose tolerance was lower in the sleep-loss condition than in the fully rested condition. Sookoian et al. ${ }^{151}$ studied 877 day workers and 474 rotating-shift workers. In comparison with day workers, rotating-shift workers had elevated fasting insulin and an increased homeostasis index, which is a measure of insulin resistance.

To define the roles of circadian rhythmicity (intrinsic effects of time of day, independent of the sleep or wake 
condition) and sleep (intrinsic effects of the sleep condition, irrespective of the time of day) on the $24 \mathrm{~h}$ variation in glucose tolerance, Van Cauter et al. ${ }^{11}$ evaluated glucose and insulin secretion rates during a $53 \mathrm{~h}$ period $-8 \mathrm{~h}$ of nocturnal sleep, followed by $28 \mathrm{~h}$ of sleep deprivation including a period of nocturnal sleep deprivation, and then $8 \mathrm{~h}$ of daytime recovery sleep. During sleep deprivation, glucose levels and insulin secretion rose to reach a maximum at a time corresponding to the beginning of the habitual sleep period. The magnitude of the rise above morning levels averaged 17 (SD 5) \% for glucose and 49 (SD 8) \% for calculated insulin secretion. Serum insulin levels did not parallel the circadian variation in insulin secretion, indicating the existence of an approximate $40 \%$ increase in insulin clearance during the night. Daytime sleep was associated with a 16 (SD 3) \% rise in glucose levels, a 55 (SD 7) \% rise in insulin secretion and a 39 (SD 5) \% rise in serum insulin. The profiles observed under these conditions indicate unequivocally that both circadian rhythmicity and sleep modulate glucose regulation ${ }^{11}$ (Fig. 4).

Further studies are necessary to evaluate whether there is a difference in glucose metabolism following intravenous infusion or oral intake of glucose or other kinds of carbohydrates under conditions of sleep deprivation. It is also important that the impact of chronic sleep debt be clarified ${ }^{1}$. Mander et al. ${ }^{124}$ observed that healthy individuals of both sexes, whose sleep had been curtailed (to less than $6.5 \mathrm{~h}$ per night) for a minimum period of 6 months, had a response to intravenous glucose similar to that of individuals who had slept longer $(7 \cdot 5-8 \cdot 5 \mathrm{~h})$, but at the cost of having markedly higher insulin secretion. This finding suggests that there might be a mechanism of metabolic adaptation when sleep debt becomes chronic. If this is the case, the initial impairment to glucose tolerance and to the responsiveness of $\beta$-cells might foster the subsequent development of insulin resistance ${ }^{1}$.

There are other explanations for the changes in glucose metabolism during conditions of sleep loss. Cortisol, whose $24 \mathrm{~h}$ rhythm is noteworthy for its robustness and persistence under a large variety of pathological conditions, is a hormone that plays an important role in glucose metabolism. A modest elevation in cortisol levels during the night was present in elderly and adult individuals who had been sleep deprived ${ }^{152-155}$. In both groups, the nocturnal elevation of cortisol could reflect an impairment of feedback inhibition on the HPA axis ${ }^{156}$.

Spiegel et al. ${ }^{32}$ observed, in eleven young men after time in bed had been restricted to $4 \mathrm{~h}$ per night for six nights (sleep-debt condition), that the evening cortisol concentrations were raised $(P=0.0001)$ and the activity of the sympathetic nervous system was increased $(P<0.02)$. The sleep-debt condition, compared with the sleep-recovery condition ( $12 \mathrm{~h}$ in bed per night for six nights), was associated with alterations in the $24 \mathrm{~h}$ profile of plasma cortisol, including a shorter quiescent period and raised concentrations in the afternoon and early evening $(P=0 \cdot 0001)$. This latter disturbance may reflect decreased efficacy of the negative-feedback regulation of the HPA axis.
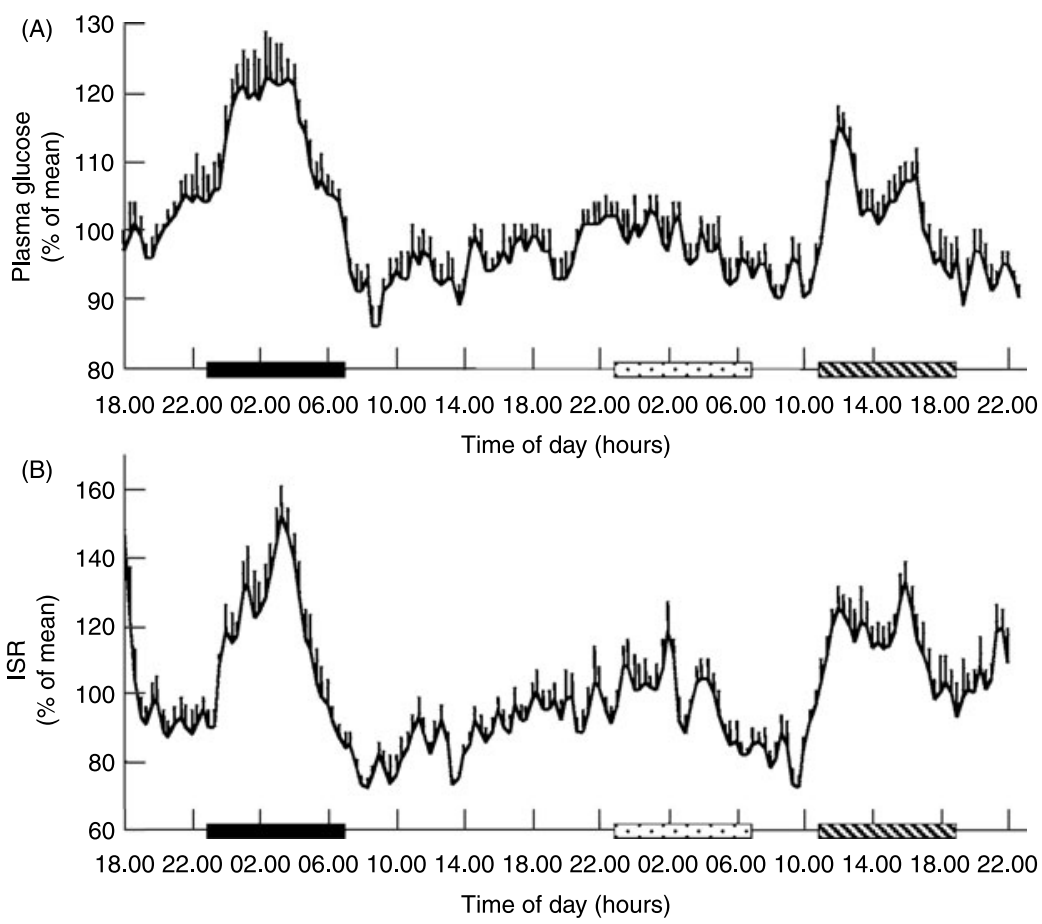

Fig. 4. Profiles of glucose (A) and insulin secretion rates (ISR) (B) in a group of eight normal young men (aged $20-27$ years) studied during a $53 \mathrm{~h}$ period including $8 \mathrm{~h}$ of nocturnal sleep $(\square)$, followed by $28 \mathrm{~h}$ of sleep deprivation including a period of nocturnal sleep deprivation ( $\mathrm{B}$ ) and $8 \mathrm{~h}$ of daytime recovery sleep $(\square)$. Data were obtained at $20 \mathrm{~min}$ intervals under continuous glucose infusion. Values are means, with their standard errors represented by vertical bars. (Adapted from Van Cauter et al. ${ }^{11}$; cited by Spiegel et al. ${ }^{1}$; used with permission from the Journal of Applied Physiology.) 
Cortisol has an immediate effect on the secretion of insulin, producing an inhibition in the absence of changes in glucose concentration $^{141}$. This effect has been demonstrated in both in vitro ${ }^{157-162}$ and in vivo studies ${ }^{163-166}$.

One of the slower effects of a rise in cortisol levels is the onset of insulin resistance $4-6 \mathrm{~h}$ afterwards ${ }^{156}$. Therefore, the normal nocturnal elevation of cortisol levels might adversely affect glucose regulation during the night and the following day. In the long term, it might contribute to agerelated reductions in glucose tolerance and insulin sensitivity. The hypothesis also suggests that the normal elevation of plasma cortisol at night, when the HPA axis is normally inhibited, would result in deleterious metabolic effects that are stronger than those that take place due to a similar elevation during the morning, when the HPA axis is fully activated ${ }^{156}$. A slow reduction of cortisol concentration in the afternoon is consistent with altered hippocampal mechanisms that control the negative feedback upon the HPA axis $^{32}$. On the other hand, some studies rule out the possibility that the circadian variations in cortisol concentrations contribute to the diurnal variation in glucose tolerance, since this tolerance is higher in the morning (when cortisol levels are high) and lower in the first half of the night (when cortisol levels are low) ${ }^{130,165}$. The coincidences of increased insulin sensitivity with high cortisol levels in the morning, and of decreased insulin sensitivity with low cortisol levels in the evening, appear to contradict the well-known adverse effects of glucocorticoids on insulin sensitivity. However, this interpretation is based on the assumption that alterations of insulin resistance are an immediate consequence of changes in cortisol concentrations $^{122}$.

Disorders in the profile of $\mathrm{GH}$ secretion might also contribute to the alterations in glucose regulation observed during sleep loss. GH is secreted in a series of pulses throughout the whole $24 \mathrm{~h}$ cycle, with greater changes in concentration, due to more frequent and larger secretory pulses, taking place during sleep ${ }^{167}$. In normal adults, peak plasma concentrations of $\mathrm{GH}$ take place during the first half of sleep, in association with the time of most SWS ${ }^{167-170}$. The amount of GH secreted during the first episode of SWS is quantitatively related to the duration $^{171,172}$ and the intensity ${ }^{173}$ of the SWS. The rapid anti-insulin-like effects of the $\mathrm{GH}$ pulse ${ }^{135}$ are responsible for reducing glucose uptake by the peripheral tissues ${ }^{1}$.

Considering the importance and the multiplicity of the metabolic actions of $\mathrm{GH}$, even when there are only minor changes in the secretion profile over the course of the $24 \mathrm{~h}$, these could be associated with significant peripheral effects $^{174}$. Plat et al. ${ }^{156}$ showed that sleep restriction was associated with a longer elevation of $\mathrm{GH}$ and an increase in cortisol levels during the night. Sleep-onset GH secretion is thought to facilitate the maintenance of stable overnight glucose levels despite the prolonged fasting condition $^{122}$. Indeed, studies that have used intravenous administrations of a low dose of synthetic GH to mimic physiological pulsatile release have shown that a primary effect is a rapid decrease in muscular glucose uptake $^{135,175}$. Spiegel et al. ${ }^{174}$ evaluated a semi-chronic partial sleep loss (sixteen consecutive nights in the clinical research centre, including three nights with $8 \mathrm{~h}$ bedtime from 23.00 to 07.00 hours, six nights with bedtime limited to a $4 \mathrm{~h}$ period from 01.00 to 05.00 hours, and seven nights with $12 \mathrm{~h}$ bedtime from 21.00 to 09.00 hours) on the $24 \mathrm{~h} \mathrm{GH}$ profile. Eleven young men were studied after six nights of restricted bedtimes ( 01.00 to 05.00 hours) and after seven nights of extended bedtimes (21.00 to 09.00 hours, the fully rested condition). After 1 week of sleep restriction, the biphasic nature of nocturnal $\mathrm{GH}$ release resulted in an extended period of elevated $\mathrm{GH}$ concentration compared with fully rested conditions. This extended exposure of peripheral tissues to higher $\mathrm{GH}$ levels may have adversely affected glucose regulation ${ }^{156}$.

All these mechanisms suggest an important impairment in glucose metabolism during sleep, especially in individuals submitted to sleep restriction or deprivation ${ }^{32}$. With humans spending a significant proportion of their lives asleep, it is not surprising that the body compensates for these periods of enforced fasting by manifesting a degree of peripheral insulin resistance, thereby maintaining circulating glucose levels. Likewise, there appears to be value in maintaining levels of circulating glucose during periods of perceived stress, in order to sustain cognitive and metabolic function $^{144}$.

These results highlight the fact that dietary care is fundamental in those individuals who are more susceptible to glucose metabolic disorders such as diabetes and insulin resistance. Accordingly, the intake of carbohydrates near bedtime should be minimal, since the little evidence that does exist suggests that intake at 22.00 hours entails a considerably stronger insulin and glucose response compared with the same intake at 10.00 hours ${ }^{176}$. This response is compatible with the considerable insulin resistance observed during the night ${ }^{177}$. In addition, it has been suggested that the intake of large amounts of food at night, during the circadian phase when there is lowest insulin sensitivity, might generate effects that predispose individuals to the onset of other metabolic disorders $^{177}$.

\section{Fat metabolism during sleep}

Recent studies have shown that night workers, with chronic sleep loss, are more predisposed to fat metabolism disorders $9,14,15,28,54,55,178,179$. These individuals present higher serum levels of $\mathrm{TAG}^{9,14,28,54,55,179}$ and cholesterol $^{14,15,178}$ compared with day workers (Table 1).

It is widely recognised that environmental factors, especially feeding, are critical for the development of those problems, and night workers have inadequate eating habits that might contribute to these problems ${ }^{28,115-118}$. Nevertheless, another body of evidence suggests that the problems might be triggered by metabolic disorders that do not depend on food intake ${ }^{28}$; rather, they are a pathogenic effect induced by a mismatch between circadian rhythms, environmental factors and social stress ${ }^{180}$. In other words, the difficulties might arise from a clash between the body clock and the environment ${ }^{181}$. Therefore, we shall now consider alterations of fat metabolism that are triggered by disruption of the sleep-wake rhythm. 
Table 1. Lipid profile disturbances in shift workers

\begin{tabular}{|c|c|c|c|}
\hline Study & Sample & Design & Results \\
\hline Ghiasvand et al. $(2006)^{15}$ & $\begin{array}{l}\text { Shift and day workers } \\
\quad(n 158 \text { and } n 266 \text { respectively) }\end{array}$ & Epidemiological study & $\begin{array}{l}\text { High total- cholesterol levels: }+72.2 \% \text { in shift workers } \\
\text { and }+50.8 \% \text { in day workers } \\
\text { High LDL-cholesterol levels: }+37.3 \% \text { in shift workers and } \\
\quad+25.4 \% \text { in day workers }\end{array}$ \\
\hline $\begin{array}{l}\text { Van Amelsvoort et al. } \\
(2004)^{228}\end{array}$ & $\begin{array}{l}\text { Shift and day workers ( } n 239 \text { and } \\
n 157 \text { respectively) }\end{array}$ & Cohort & $\begin{array}{l}\text { Decreased LDL:HDL-cholesterol ratio: }-0.13 \mathrm{mmol} / \mathrm{l} \\
\text { in day workers and }-0.33 \mathrm{mmol} / \mathrm{l} \text { in shift workers }\end{array}$ \\
\hline Karlsson et al. (2003) ${ }^{14}$ & $\begin{array}{l}\text { Day workers and three-shift workers } \\
\text { in two plants ( } n 665 \text { and } n 659 \text { respectively) }\end{array}$ & Cross-sectional data & $\begin{array}{l}\text { High TAG levels: }+32.5 \% \text { in shift workers } \\
\text { and }+25.1 \% \text { in day workers } \\
\text { Low HDL-cholesterol levels: }+7.6 \% \text { in shift workers } \\
\text { and }+3.9 \% \text { in day workers }\end{array}$ \\
\hline Karlsson et al. $(2001)^{18}$ & $\begin{array}{l}\text { Shift and day workers ( } n 7909 \text { and } \\
n 19576 \text { respectively) }\end{array}$ & Cross-sectional data & $\begin{array}{l}\text { High TAG levels: }+31.5 \% \text { in shift workers } \\
\text { and }+28.5 \% \text { in men day workers aged } 40 \text { years; }+13.7 \% \\
\text { in shift workers and }+9.6 \% \text { in women day workers } \\
\text { aged } 40 \text { years; }+30 \% \text { in shift workers and }+25.5 \% \\
\text { in women day workers aged } 60 \text { years } \\
\text { Low HDL-cholesterol levels: }+26.7 \% \text { in shift workers } \\
\text { and }+17.9 \% \text { in men day workers aged } 30 \text { years; }+27.8 \% \\
\text { in shift workers and }+20.6 \% \text { in men day workers aged } 60 \\
\text { years; }+18.3 \% \text { in shift workers and }+8.6 \% \text { in women day } \\
\text { workers aged } 30 \text { years; }+14.7 \% \text { in shift workers and }+10.8 \% \\
\text { in women day workers aged } 50 \text { years }\end{array}$ \\
\hline Nakamura et al. $(1997)^{9}$ & $\begin{array}{l}\text { Three-shift workers, two-shift workers } \\
\text { and day workers used as a control } \\
\text { group ( } n 33, n 27 \text { and } n 239 \text { respectively) }\end{array}$ & $\begin{array}{l}\text { Cross-sectional study for an industrial } \\
\text { male, blue-collar population }\end{array}$ & $\begin{array}{l}\text { High mean total cholesterol levels: } 5.70(\mathrm{SD} 1.19) \mathrm{mmol} / \mathrm{l} \\
\text { in three-shift workers, } 4.81(\mathrm{SD} 1.01) \mathrm{mmol} / \mathrm{l} \text { in two-shift } \\
\text { workers and } 4.98(\mathrm{SD} 0.95) \mathrm{mmo} / \mathrm{l} \text { in day workers }\end{array}$ \\
\hline Romon et al. $(1992)^{28}$ & $\begin{array}{l}\text { Shift workers and day workers used as } \\
\text { control ( } n 73 \text { and } n 73 \text { respectively) }\end{array}$ & Cross-sectional survey & $\begin{array}{l}\text { High TAG levels: } 1.26 \mathrm{mmol} / / \text { in shift workers } \\
\text { and } 1.03 \mathrm{mmol} / / \mathrm{in} \text { day workers } \\
\text { Cholesterol and } \mathrm{HDL} \text {-cholesterol levels: similar for both groups }\end{array}$ \\
\hline Nagaya et al. $(2002)^{56}$ & $\begin{array}{l}\text { Day- and shift workers ( } n 2824 \text { and } \\
n 826 \text { respectively) }\end{array}$ & Cross-sectional study & $\begin{array}{l}\text { High TAG levels:levels: }+28 \cdot 7 \% \text { in day workers } \\
\text { and }+31.2 \% \text { in shift workers }\end{array}$ \\
\hline Knutsson et al. $(1988)^{55}$ & $\begin{array}{l}\text { Shift- and day workers ( } n 361 \text { and } \\
n 240 \text { respectively) }\end{array}$ & Cross-sectional study & $\begin{array}{l}\text { High TAG levels: } 1.61 \mathrm{mmol} / \mathrm{l} \text { in shift workers } \\
\text { and } 1.43 \mathrm{mmol} / \mathrm{l} \text { in day workers }\end{array}$ \\
\hline
\end{tabular}




\section{Circadian control of fat metabolism}

The supply of TAG from the adipocytes results from a balance between the uptake and release of NEFA. These fatty acids are formed by the hydrolysis of circulating TAG by the lipoprotein lipase (LPL) enzyme ${ }^{182}$ and by the lipolysis of TAG into NEFA and glycerol by hormonesensitive lipase ${ }^{183}$. These processes are reciprocally regulated, suggesting an inverse relationship between the activities of LPL and hormone-sensitive lipase ${ }^{184}$.

Dramatic diurnal variations in adipocyte lipolysis and lipogenesis occur in mammals. When an animal sleeps, rates of lipolysis increase, resulting in increased release of NEFA into the circulation. In contrast, when an animal is awake, rates of lipolysis decrease, with a concomitant increase in lipogenesis. Diurnal variations in adipose TAG turnover have been explained primarily in terms of reciprocal changes in neurohumoral influences promoting lipolysis and lipogenesis ${ }^{64}$. According to the 'lipogenic-lipolytic' theory of Armstrong ${ }^{115}$, daytime food intake is associated with glucose metabolism and fat deposition, and nocturnal fasting with fat metabolism. It follows that fat metabolism will be more active during the night and fat oxidation takes place mainly at this time ${ }^{167,185}$.

Hormones that acutely affect lipolysis in human adipocytes are catecholamines (adrenaline and noradrenaline) and insulin ${ }^{186}$. Circulating $\mathrm{GH}$ also plays a fundamental role in the regulation of fat metabolism ${ }^{187,188}$, generally increasing energy flow in the lipid transportation system by stimulation of lipolysis in adipose tissue ${ }^{189,190}$. Some authors suggest that $\mathrm{GH}$ is the main hormone in the control of lipolysis. Interestingly, peak production of this hormone occurs during the night, suggesting that this might be the pathway through which lipolysis is stimulated during sleep $^{191}$. In addition to increases in GH concentration, adrenocorticotropin $^{192}$ and prolactin ${ }^{193}$ also rise and then fall during the night, and have also been implicated in the regulation of lipolysis ${ }^{194,195}$. These results support the view that the circadian variations of several endocrines modulate both fat deposition and utilisation during a $24 \mathrm{~h}$ period.

\section{Circadian rhythm of lipid tolerance and cholesterol biosynthesis}

TAG concentrations in the blood show a circadian variation, with maximum values around 03.00 to 04.00 hours and minimum values at noon ${ }^{196}$. Morgan et al. ${ }^{197}$ observed a marked increase of plasma TAG during the night and its dissociation into two significant components. The first was related to the internal body clock, and the second to the time after waking. This increase in TAG is possibly due to an impairment in lipid tolerance during the night - that is, an impaired postprandial TAG clearance ${ }^{198}$ - in turn due to insufficient insulin activity at this time ${ }^{196,197,199}$; the result will be a reduction in the activity of LPL and decreased hydrolysis of plasma TAG ${ }^{200}$. Consequently, concentrations of TAG in the blood will be high during the night ${ }^{14,200}$.

Other possible causes of nocturnal lipid intolerance are that the clearance of TAG from the circulation, or the suppression of hepatic synthesis and/or secretion of TAG, is impaired $^{198}$. Lemberger et al. ${ }^{201}$ state that the $\alpha$-sub-type hepatic PPAR indirectly influences TAG hydrolysis, and so affects the levels of circulating TAG, via regulation of the synthesis of apo CIII (a lipoprotein fraction that is an inhibitor of LPL).

Studies involving the hepatic lipase enzyme suggest that its activity is positively related to serum concentrations of $\mathrm{TAG}^{202}$ and that hypertriacylglycerolaemia is a characteristic of hepatic lipase deficiency ${ }^{203}$. Moreover, this enzyme has been implicated in impairment of the postprandial clearance of lipoproteins ${ }^{204}$. Consequently, it is possible that reduced levels of hepatic lipase at night might also contribute to nocturnal lipid intolerance ${ }^{198}$.

Advances of the sleep-wake cycle ${ }^{205}$ and simulated shift work $^{206}$ have both revealed an increase in the postprandial response of TAG in the night. It is known that factors such as the rate of gastric emptying, TAG hydrolysis in the intestine, and intestinal motility might influence the rate of TAG flow into the circulation ${ }^{207}$, and insulin resistance has also been suggested to be a factor contributing to this increase in postprandial $\mathrm{TAG}^{208}$. Since LPL has a reduced activity at night and plays an important role in the regulation of postprandial TAG clearance ${ }^{209}$, higher levels of TAG are observed after food intake at night compared with the daytime $^{199}$.

The decrease of lipid tolerance in the night-time can cause high levels of TAG in the circulation, especially in association with food intake. Traditionally, fasting plasma TAG concentrations have not been recognised as an independent risk factor affecting the pathogenesis and progression of $\mathrm{CHD}^{210}$. However, more recent epidemiological evidence suggests that the relative importance of TAG as a risk factor for CHD may have been underestimated. A large meta-analysis of seventeen population-based prospective studies showed that plasma TAG concentration was an independent risk factor for $\mathrm{CHD}^{211}$. This analysis also showed that plasma TAG concentrations were particularly important in relation to CHD risk in women; an increase in plasma TAG concentration increased cardiovascular risk by $76 \%$ in women compared with $32 \%$ in men $^{211}$.

Current evidence ${ }^{185,212}$ indicates that the rates of endogenous cholesterol biosynthesis in man are subject to large changes over the course of the day ${ }^{185,212-214}$ and increase at night. The concentration of HDL-cholesterol also shows a circadian variation, which is phased opposite to that of TAG, with minimum values at around 04.00 hours and maximum values around noon ${ }^{196}$. Miettinen ${ }^{213}$ observed an increase in the cholesterol precursors squalene and lanosterol, with maximum values found between midnight and 04.00 hours. Parker et al. ${ }^{185}$ observed a nocturnal increase in plasma levels of mevalonate, a precursor of cholesterol biosynthesis whose production is controlled by hydroxymethylglutaryl-CoA reductase ${ }^{215}$, and these were correlated with the rate of cholesterol production $^{216-218}$.

The behaviour of cholesterol metabolism in human subjects during sleep deprivation ${ }^{219}$ and rotating-shift systems $^{53}$ has led to the suggestion that changes in the sleep-wake and/or light-dark cycles might be involved. On the other hand, Cella et al. ${ }^{220}$ observed that, with alterations in the sleep-wake and/or light-dark cycles but with no changes to meal times, the diurnal pattern of cholesterol 
synthesis was unaltered; this result shows that the rhythm is more strongly regulated by meal times rather than by the sleep-wake and light-dark cycles. However, in other studies carried out upon animals, both the circadian rhythm and meal times played important roles in the regulation of the diurnal variation of cholesterol synthesis ${ }^{205}$. It has also been found that eating at night leads to an increase in the LDL:HDL ratio ${ }^{25}$.

The increase of GH in SWS might be associated with the increase in cholesterol synthesis during the night ${ }^{167,185}$. Takahashi et al. ${ }^{167}$ and Parker et al. ${ }^{185}$ have suggested that $\mathrm{GH}$ might have a direct regulating effect on cholesterol synthesis due to the strong temporal association between the increases of $\mathrm{GH}$ and mevalonate in the night. The hypothesis is that $\beta$-oxidation, which also is increased during the night, might be the pathway for the oxidation of the NEFA to supply the two carbon fragments necessary to condense and form hydroxymethylglutaryl-CoA, the immediate precursor of mevalonate ${ }^{167,185}$. However, Boyle et al. ${ }^{221}$ and Cella et $a .^{220}$ observed that an abrupt change in sleep time, with the resulting change in release of $\mathrm{GH}$, was not associated with detectable changes in cholesterol synthesis.

Cella et al. ${ }^{220}$ showed that TSH, normally inhibited by nocturnal sleep, had a peak coinciding with the maximum rate of cholesterol synthesis on days with normal amounts of sleep at night; by contrast, a twofold increase in the amplitude of the TSH rhythm was observed during sleep deprivation $^{222-224}$. This major alteration in the profile of TSH concentration was associated with a modest elevation in the peak of the rhythm of cholesterol synthesis, and these simultaneous changes were reflected in an increase in the cross-correlation between them ${ }^{220}$. These observations support the view that TSH might exert an effect on cholesterol synthesis, mainly during sleep deprivation ${ }^{220}$. Under normal sleep-wake conditions, the diurnal variation in secretion of thyroid hormone has a low amplitude and its circadian rhythm might go undetected ${ }^{224,225}$. During sleep deprivation, by contrast, a nocturnal increase in this hormone parallels an increase of $\mathrm{TSH}^{225}$. Since the activity of the hydroxymethylglutaryl-CoA reductase enzyme is influenced by this thyroid hormone ${ }^{226,227}$, it is conceivable that the activation of the pituitary-thyroid axis during sleep deprivation exerts a modest influence on cholesterol synthesis $^{220}$.

Therefore, it is possible that the normal increases in levels of TAG and cholesterol at night is accentuated by sleep loss and abnormal nocturnal food intake, thus contributing to the risk of CVD. Many studies show that physiological events that control lipid metabolism are strongly influenced by the sleep-wake cycle. Thus, it is reasonable to suppose that interruption of the sleep-wake cycle, resulting in a decreased sleep time, can impair lipid metabolism. This impairment is demonstrated in studies that show that shift workers, who sleep less than $5 \mathrm{~h}$ on their working days ${ }^{16}$, have a greater frequency of disorders of lipid metabolism.

The role of sleep loss in fat metabolism is an exciting new field of study, and is believed to result in an increased incidence of dyslipidaemias. Elucidation of the mechanisms involved might have profound implications for an understanding of these disorders. In the future, it will be necessary to investigate whether these processes have an impact on both susceptibility to dyslipidaemias and on susceptibility to the development of the potentially debilitating comorbidities associated with disorders of fat metabolism. Nevertheless, it might prove difficult to show unequivocally that there is a causal relationship between sleeps of short duration and problems with lipid metabolism.

\section{Conclusion}

We conclude that sleep affects the body's nutritional control, and that alterations to an individual's sleep pattern might stimulate food intake and so contribute to the onset of disorders of glucose and fat metabolism. Sleep loss also contributes to the onset of insulin resistance, type 2 diabetes and obesity, as direct consequences of the influence of sleep on glucose metabolism and of an alteration in feeding behaviour generated by appetite dysregulation. It is also important to acknowledge that the laboratory analyses do not prove causality between sleeps of short sleep duration and diabetes. However, the current experimental literature involves only very small numbers of participants who are nearly all men and young. Experimental evidence from older individuals and from women of all ages is required to confirm that sleep loss causes metabolic problems in the population as a whole. The increase in blood lipids during the night, associated with altered eating patterns, seems to contribute to the onset of dyslipidaemias. Indeed, not only adequate sleep time but also balanced eating habits are of fundamental importance for the maintenance of health, and both should be encouraged by health professionals. In particular, individuals with chronic sleep loss, such as night workers, deserve specific nutritional advice. Further studies are required so that the detailed needs of these individuals can be better understood.

\section{Acknowledgements}

C. A. C. was primarily responsible for the literature revision of the study, supervised its execution and reviewed each step of writing. I. Z., M. D. and H. G. P. were jointly responsible for the literature revision of the study. B. E. and J. W. provided assistance in all literature revision and execution of the study and for the revision of the English language. S. T. and M. T. de M. assisted in execution of all parts of the study. We acknowledge AFIP, Sleep Institute, FAPESP, CEDIP/FAPESP (no. 998/14303-3), CEPE, UNIFESP, CENESP/UNIFESP, FADA, CEMSA, CAPES, CNPQ and FADA/UNIFESP.

\section{References}

1. Spiegel K, Knutson K, Leproult R, Tasali E \& Van Cauter E (2005) Sleep loss: a novel risk factor for insulin resistance and type 2 diabetes. J Appl Physiol 99, 2008-2019.

2. Kripke DF, Simons RN, Garfinkel L \& Hammond EC (1979) Short and long sleep and sleeping pills. Is increased mortality associated? Arch Gen Psychiatry 36, 103-116.

3. National Sleep Foundation (2002) 2002 "Sleep in America" Poll. Washington, DC: National Sleep Foundation.

4. Vioque J, Torres A \& Quiles J (2000) Time spent watching television, sleep duration and obesity in adults living in 
Valencia, Spain. Int J Obes Relat Metab Disord 24, $1683-1688$.

5. Holmback U, Forslund A, Forslund J, Hambraeus L, Lennernas M, Lowden A, Stridsberg M \& Akerstedt T (2002) Metabolic responses to nocturnal eating in men are affected by sources of dietary energy. J Nutr 132, $1892-1899$.

6. Kripke DF, Garfinkel L, Wingard DL, Klauber MR \& Marler MR (2002) Mortality associated with sleep duration and insomnia. Arch Gen Psychiatry 59, 131-136.

7. Taheri S, Lin L, Austin D, Young T \& Mignot E (2004) Short sleep duration is associated with reduced leptin, elevated ghrelin, and increased body mass index. PLoS Med 1, e62.

8. Knutsson A (1989) Shift work and coronary heart disease. Scand J Soc Med Suppl 44, 1-36.

9. Nakamura K, Shimai S, Kikuchi S, Tominaga K, Takahashi H, Tanaka M, Nakano S, Motohashi Y, Nakadaira H \& Yamamoto M (1997) Shift work and risk factors for coronary heart disease in Japanese blue-collar workers: serum lipids and anthropometric characteristics. Occup Med (Lond) 47, 142-146.

10. Scheen AJ (1999) Clinical study of the month. Does chronic sleep deprivation predispose to metabolic syndrome? (article in French). Rev Méd Liège 54, 898-900.

11. Van Cauter E, Blackman JD, Roland D, Spire JP, Refetoff S \& Polonsky KS (1991) Modulation of glucose regulation and insulin secretion by circadian rhythmicity and sleep. J Clin Invest 88, 934-942.

12. Gottlieb DJ, Punjabi NM, Newman AB, Resnick HE, Redline S, Baldwin CM \& Nieto FJ (2005) Association of sleep time with diabetes mellitus and impaired glucose tolerance. Arch Intern Med 165, 863-867.

13. Knutsson A (1989) Relationships between serum triglycerides and $\gamma$-glutamyltransferase among shift and day workers. J Intern Med 226, 337-339.

14. Karlsson BH, Knutsson AK, Lindahl BO \& Alfredsson LS (2003) Metabolic disturbances in male workers with rotating three-shift work. Results of the WOLF study. Int Arch Occup Environ Health 76, 424-430.

15. Ghiasvand M, Heshmat R, Golpira R, Haghpanah V, Soleimani A, Shoushtarizadeh P, Tavangar SM \& Larijani B (2006) Shift working and risk of lipid disorders: a crosssectional study. Lipids Health Dis 5, 9.

16. Bliwise DL (1996) Historical change in the report of daytime fatigue. Sleep 19, 462-464.

17. Birketvedt GS, Florholmen J, Sundsfjord J, Osterud B, Dinges D, Bilker W \& Stunkard A (1999) Behavioral and neuroendocrine characteristics of the night-eating syndrome. JAMA 282, 657-663.

18. Karlsson B, Knutsson A \& Lindahl B (2001) Is there an association between shift work and having a metabolic syndrome? Results from a population based study of 27,485 people. Occup Environ Med 58, 747-752.

19. Lowden A, Holmback U, Akerstedt T, Forslund A, Forslund J \& Lennernas M (2001) Time of day type of food - relation to mood and hunger during 24 hours of constant conditions. J Hum Ergol (Tokyo) 30, 381-386.

20. Parkes KR (2002) Shift work and age as interactive predictors of BMI among offshore workers. Scand J Work Environ Health 28, 64-71.

21. Di Lorenzo L, De Pergola G, Zocchetti C, L'Abbate N, Basso A, Pannacciulli N, Cignarelli M, Giorgino R \& Soleo L (2003) Effect of shift work on body mass index: results of a study performed in 319 glucose-tolerant men working in a Southern Italian industry. Int J Obes Relat Metab Disord 27, $1353-1358$.
22. Ishizaki M, Morikawa $\mathrm{Y}$, Nakagawa $\mathrm{H}$, Honda $\mathrm{R}$, Kawakami N, Haratani T, Kobayashi F, Araki S \& Yamada Y (2004) The influence of work characteristics on body mass index and waist to hip ratio in Japanese employees. Ind Health 42, 41-49.

23. Waterhouse J, Akerstedt T, Lennernas M \& Arendt J (1999) Chronobiology and nutrition: internal and external factors. Can J Diabetes Care 23, Suppl. 2, 82-88.

24. Waterhouse J, Buckley P, Edwards B \& Reilly T (2003) Measurement of, and some reasons for, differences in eating habits between night and day workers. Chronobiol Int 20, $1075-1092$

25. Lennernas M, Akerstedt T \& Hambraeus L (1994) Nocturnal eating and serum cholesterol of three-shift workers. Scand J Work Environ Health 20, 401-406.

26. van Amelsvoort LG, Schouten EG \& Kok FJ (1999) Duration of shiftwork related to body mass index and waist to hip ratio. Int J Obes Relat Metab Disord 23, 973-978.

27. Svatikova A, Wolk R, Gami AS, Pohanka M \& Somers VK (2005) Interactions between obstructive sleep apnea and the metabolic syndrome. Curr Diab Rep 5, 53-58.

28. Romon M, Nuttens MC, Fievet C, Pot P, Bard JM, Furon D \& Fruchart JC (1992) Increased triglyceride levels in shift workers. Am J Med 93, 259-262.

29. Ayas NT, White DP, Manson JE, Stampfer MJ, Speizer FE, Malhotra A \& Hu FB (2003) A prospective study of sleep duration and coronary heart disease in women. Arch Intern Med 163, 205-209.

30. Kawakami N, Takatsuka N \& Shimizu H (2004) Sleep disturbance and onset of type 2 diabetes. Diabetes Care 27, $282-283$

31. Nilsson PM, Roost M, Engstrom G, Hedblad B \& Berglund $G$ (2004) Incidence of diabetes in middle-aged men is related to sleep disturbances. Diabetes Care 27, 2464-2469.

32. Spiegel K, Leproult R \& Van Cauter E (1999) Impact of sleep debt on metabolic and endocrine function. Lancet 354, $1435-1439$.

33. Spiegel K, Tasali E, Penev P \& Van Cauter E (2004) Brief communication: sleep curtailment in healthy young men is associated with decreased leptin levels, elevated ghrelin levels, and increased hunger and appetite. Ann Intern Med 141, 846-850.

34. Rechtschaffen A, Bergmann BM, Everson CA, Kushida CA \& Gilliland MA (1989) Sleep deprivation in the rat: $\mathrm{X}$. Integration and discussion of the findings. Sleep 12, 68-87.

35. Everson CA, Bergmann BM \& Rechtschaffen A (1989) Sleep deprivation in the rat: III. Total sleep deprivation. Sleep 12, 13-21.

36. Kushida CA, Bergmann BM \& Rechtschaffen A (1989) Sleep deprivation in the rat: IV. Paradoxical sleep deprivation. Sleep 12, 22-30.

37. Patchev V, Felszeghy K \& Koranyi L (1991) Neuroendocrine and neurochemical consequences of long-term sleep deprivation in rats: similarities to some features of depression. Homeost Health Dis 33, 97-108.

38. Youngblood BD, Zhou J, Smagin GN, Ryan DH \& Harris RB (1997) Sleep deprivation by the "flower pot" technique and spatial reference memory. Physiol Behav 61, 249-256.

39. Rechtschaffen A \& Bergmann BM (2002) Sleep deprivation in the rat: an update of the 1989 paper. Sleep 25, 18-24.

40. Papakonstantinou E, Ryan DH \& Harris RB (2003) Dietary fish oil does not protect rats exposed to restraint or sleep deprivation stress. Physiol Behav 78, 759-765. 
41. Martins PJ, D'Almeida V, Nobrega JN \& Tufik S (2006) A reassessment of the hyperphagia/weight-loss paradox during sleep deprivation. Sleep 29, 1233-1238.

42. Flier JS \& Elmquist JK (2004) A good night's sleep: future antidote to the obesity epidemic? Ann Intern Med 141, $885-886$.

43. Bonnet MH \& Arand DL (1995) We are chronically sleep deprived. Sleep 18, 908-911.

44. Hasler G, Buysse DJ, Klaghofer R, Gamma A, Ajdacic V, Eich D, Rossler W \& Angst J (2004) The association between short sleep duration and obesity in young adults: a 13-year prospective study. Sleep 27, 661-666.

45. Vorona R, Winn M, Babineau T, Eng B, Feldman H \& Ware $\mathrm{J}$ (2005) Overweight and obese patients in a primary care population report less sleep than patients with a normal body mass index. Arch Intern Med 165, 25-30.

46. Padez C, Mourao I, Moreira P \& Rosado V (2005) Prevalence and risk factors for overweight and obesity in Portuguese children. Acta Paediatr 94, 1550-1557.

47. Reilly JJ, Armstrong J, Dorosty AR, Emmett PM, Ness A, Rogers I, Steer C, Sherriff A \& Avon Longitudinal Study of Parents and Children Study Team (2005) Early life risk factors for obesity in childhood: cohort study. BMJ 330, 1357.

48. Chaput JP, Brunet M \& Tremblay A (2006) Relationship between short sleeping hours and childhood overweight/obesity: results from the 'Quebec en Forme' Project. Int $J$ Obesity (Lond) 30, 1080-1085.

49. Gupta NK, Mueller WH, Chan W \& Meininger JC (2002) Is obesity associated with poor sleep quality in adolescents? Am J Hum Biol 14, 762-768.

50. Knutson KL (2005) Sex differences in the association between sleep and body mass index in adolescents. J Pediatr 147, 830-834.

51. Chen MY, Wang EK \& Jeng YJ (2006) Adequate sleep among adolescents is positively associated with health status and health-related behaviors. BMC Public Health 6, 59.

52. Waterhouse J, Kao S, Edwards B, Atkinson G \& Reilly T (2006) Factors associated with food intake in passengers on long-haul flights. Chronobiol Int 23, 985-1007.

53. Theorell T \& Akerstedt T (1976) Day and night work: changes in cholesterol, uric acid, glucose and potassium in serum and in circadian patterns of urinary catecholamine excretion. A longitudinal cross-over study of railway workers. Acta Med Scand 200, 47-53.

54. Orth-Gomér K (1983) Intervention on coronary risk factors by adapting a shift work schedule to biologic rhythmicity. Psychosom Med 45, 407-415.

55. Knutsson A, Akerstedt T \& Jonsson BG (1988) Prevalence of risk factors for coronary artery disease among day and shift workers. Scand J Work Environ Health 14, 317-321.

56. Nagaya T, Yoshida H, Takahashi H \& Kawai M (2002) Markers of insulin resistance in day and shift workers aged 30-59 years. Int Arch Occup Environ Health 75, 562-568.

57. Reilly T, Waterhouse J \& Atkinson G (1997) Aging, rhythms of physical performance, and adjustment to changes in the sleep-activity cycle. Occup Environ Med $\mathbf{5 4}, 812-816$.

58. Waterhouse J, Minors D \& Redfern P (1997) Some comments on the measurement of circadian rhythms after time-zone transitions and during night work. Chronobiol Int 14, 125-132.

59. Waterhouse J, Jones K, Edwards B, Harrison Y, Nevill A \& Reilly T (2004) Lack of evidence for a marked endogenous component determining food intake in humans during forced desynchrony. Chronobiol Int 21, 445-468.
60. Reinberg A, Migraine C, Apfelbaum M, Brigant L, Ghata J, Vieux N, Laporte A \& Nicolai (1979) Circadian and ultradian rhythms in the feeding behaviour and nutrient intakes of oil refinery operators with shift-work every 3-4 days. Diabete Metab 5, 33-41.

61. Krauchi K, Wirz-Justice A \& Graw P (1990) The relationship of affective state to dietary preference: winter depression and light therapy as a model. J Affect Disord 20, 43-53.

62. Lennernas M, Hambraeus L \& Akerstedt T (1995) Shift related dietary intake in day and shift workers. Appetite $\mathbf{2 5}$, 253-265.

63. Waterhouse J, Kao S, Edwards B, Weinert D, Atkinson G \& Reilly T (2005) Transient changes in the pattern of food intake following a simulated time-zone transition to the east across eight time zones. Chronobiol Int 22, 299-319.

64. Bray MS \& Young ME (2007) Circadian rhythms in the development of obesity: potential role for the circadian clock within the adipocyte. Obes Rev 8, 169-181.

65. Rutenfranz J, Knauth P \& Fisher FM (1989) Efeito dos turnos nas pessoas (Effects of shift work on individuals). In Trabalho em Turnos e Noturno, pp. 41-70 [J Rutenfranz, P Knauth and FM Fisher, editors]. Sao Paulo, Brazil: Hucitec.

66. Steiger A (2004) Eating and sleeping - their relationship to ghrelin and leptin. Am J Physiol Regul Integr Comp Physiol 287, R1031-R1032.

67. Kojima M, Hosoda H, Date Y, Nakazato M, Matsuo H \& Kangawa K (1999) Ghrelin is a growth-hormone-releasing acylated peptide from stomach. Nature 402, 656-660.

68. Bodosi B, Gardi J, Hajdu I, Szentirmai E, Obal F Jr \& Krueger JM (2004) Rhythms of ghrelin, leptin, and sleep in rats: effects of the normal diurnal cycle, restricted feeding, and sleep deprivation. Am J Physiol Regul Integr Comp Physiol 287, R1071-R1079.

69. Mullington JM, Chan JL, Van Dongen HP, Szuba MP, Samaras J, Price NJ, Meier-Ewert HK, Dinges DF \& Mantzoros CS (2003) Sleep loss reduces diurnal rhythm amplitude of leptin in healthy men. $J$ Neuroendocrinol $\mathbf{1 5}$, $851-854$.

70. Spiegel K, Leproult R, Tasali E, Penev P \& Van Cauter E (2003) Sleep curtailment results in decreased leptin levels and increased hunger and appetite. Sleep 26, A174.

71. Spiegel K, Leproult R, L'Hermite-Baleriaux M, Copinschi G, Penev PD \& Van Cauter E (2004) Leptin levels are dependent on sleep duration: relationships with sympathovagal balance, carbohydrate regulation, cortisol, and thyrotropin. J Clin Endocrinol Metab 89, 5762-5771.

72. Reseland JE, Anderssen SA, Solvoll K, Hjermann I, Urdal P, Holme I \& Drevon CA (2001) Effect of long-term changes in diet and exercise on plasma leptin concentrations. Am J Clin Nutr 73, 240-245.

73. Ahima RS, Prabakaran D, Mantzoros C, Qu D, Lowell B, Maratos-Flier E \& Flier JS (1996) Role of leptin in the neuroendocrine response to fasting. Nature 382, 250-252.

74. Ahima RS, Dushay J, Flier SN, Prabakaran D \& Flier JS (1997) Leptin accelerates the onset of puberty in normal female mice. J Clin Invest 99, 391-395.

75. Heiman ML, Ahima RS, Craft LS, Schoner B, Stephens TW \& Flier JS (1997) Leptin inhibition of the hypothalamicpituitary-adrenal axis in response to stress. Endocrinology 138, 3859-3863.

76. Yu WH, Kimura M, Walczewska A, Karanth S \& McCann SM (1997) Role of leptin in hypothalamic-pituitary function. Proc Natl Acad Sci USA 94, 1023-1028.

77. Friedman JM \& Halaas JL (1998) Leptin and the regulation of body weight in mammals. Nature 395, 763-770. 
78. Takeda S, Elefteriou F, Levasseur R, Liu X, Zhao L, Parker KL, Armstrong D, Ducy P \& Karsenty G (2002) Leptin regulates bone formation via the sympathetic nervous system. Cell 111, 305-317.

79. Takeda S, Elefteriou F \& Karsenty G (2003) Common endocrine control of body weight, reproduction, and bone mass. Ann Rev Nutr 23, 403-411.

80. Elefteriou F, Ahn JD, Takeda S, Starbuck M, Yang X, Liu X, Kondo H, Richards WG, Bannon TW, Noda M, Clement K, Vaisse C \& Karsenty G (2005) Leptin regulation of bone resorption by the sympathetic nervous system and CART. Nature 434, 514-520.

81. Marx J (2003) Cellular warriors at the battle of the bulge. Science 299, 846-849.

82. Moran TH, Aja S \& Ladenheim EE (2006) Leptin modulation of peripheral controls of meal size. Physiol Behav 89, 511-516.

83. Sinton CM, Fitch TE \& Gershenfeld HK (1999) The effects of leptin on REM sleep and slow wave delta in rats are reversed by food deprivation. J Sleep Res 8, 197-203.

84. Simon C, Gronfier C, Schlienger JL \& Brandenberger G (1998) Circadian and ultradian variations of leptin in normal man under continuous enteral nutrition: relationship to sleep and body temperature. J Clin Endocrinol Metab 83, $1893-1899$.

85. Schoeller DA, Cella LK, Sinha MK \& Caro JF (1997) Entrainment of the diurnal rhythm of plasma leptin to meal timing. J Clin Invest 100, 1882-1887.

86. Chaput JP, Despres JP, Bouchard C \& Tremblay A (2007) Short sleep duration is associated with reduced leptin levels and increased adiposity: results from the Quebec family study. Obesity (Silver Spring) 15, 253-261.

87. Rayner DV \& Trayhurn P (2001) Regulation of leptin production: sympathetic nervous system interactions. $J \mathrm{Mol}$ Med 79, 8-20.

88. Newcomer JW, Selke G, Melson AK, Gross J, Vogler GP \& Dagogo-Jack S (1998) Dose-dependent cortisol-induced increases in plasma leptin concentration in healthy humans. Arch Gen Psychiatry 55, 995-1000.

89. Wauters M, Considine RV \& Van Gaal LF (2000) Human leptin: from an adipocyte hormone to an endocrine mediator. Eur J Endocrinol 143, 293-311.

90. Flier JS (2004) Obesity wars: molecular progress confronts an expanding epidemic. Cell 116, 337-350.

91. Mantzoros CS, Ozata M \& Negrao AB (2001) Synchronicity of frequently sampled thyrotropin (TSH) and leptin concentrations in healthy adults and leptin-deficient subjects: evidence for possible partial TSH regulation by leptin in humans. J Clin Endocrinol Metab 86, 3284-3291.

92. Seoane LM, Carro E, Tovar S, Casanueva FF \& Dieguez C (2000) Regulation of in vivo TSH secretion by leptin. Regul Pept 92, 25-29.

93. Ortiga-Carvalho TM, Oliveira KJ, Soares BA \& PazosMoura CC (2002) The role of leptin in the regulation of TSH secretion in the fed state: in vivo and in vitro studies. $J$ Endocrinol 174, 121-125.

94. Corbetta S, Englaro P, Giambona S, Persani L, Blum WF \& Beck-Peccoz P (1997) Lack of effects of circulating thyroid hormone levels on serum leptin concentrations. Eur $J$ Endocrinol 137, 659-663.

95. Kristensen K, Pedersen SB, Langdahl BL \& Richelsen B (1999) Regulation of leptin by thyroid hormone in humans: studies in vivo and in vitro. Metabolism 48, 1603-1607.

96. Cowley MA, Smith RG, Diano S, et al. (2003) The distribution and mechanism of action of ghrelin in the CNS demonstrates a novel hypothalamic circuit regulating energy homeostasis. Neuron 37, 649-661.
97. van der Lely AJ, Tschop M, Heiman ML \& Ghigo E (2004) Biological, physiological, pathophysiological, and pharmacological aspects of ghrelin. Endocr Rev 25, 426-457.

98. Wren AM, Small CJ, Ward HL, Murphy KG, Dakin CL, Taheri S, Kennedy AR, Roberts GH, Morgan DG, Ghatei MA \& Bloom SR (2000) The novel hypothalamic peptide ghrelin stimulates food intake and growth hormone secretion. Endocrinology 141, 4325-4328.

99. Cummings DE, Purnell JQ, Frayo RS, Schmidova K, Wisse BE \& Weigle DS (2001) A preprandial rise in plasma ghrelin levels suggests a role in meal initiation in humans. Diabetes 50, 1714-1719.

100. Bagnasco M, Tulipano G, Melis MR, Argiolas A, Cocchi D \& Muller EE (2003) Endogenous ghrelin is an orexigenic peptide acting in the arcuate nucleus in response to fasting. Regul Pept 111, 161-167.

101. Masuda Y, Tanaka T, Inomata N, Ohnuma N, Tanaka S, Itoh Z, Hosoda H, Kojima M \& Kangawa K (2000) Ghrelin stimulates gastric acid secretion and motility in rats. Biochem Biophys Res Comm 276, 905-908.

102. Tschop M, Smiley DL \& Heiman ML (2000) Ghrelin induces adiposity in rodents. Nature 407, 908-913.

103. Kalra SP, Dube MG, Pu S, Xu B, Horvath TL \& Kalra PS (1999) Interacting appetite-regulating pathways in the hypothalamic regulation of body weight. Endocrine Rev 20, 68-100.

104. Wren AM, Seal LJ, Cohen MA, Brynes AE, Frost GS, Murphy KG, Dhillo WS, Ghatei MA \& Bloom SR (2001) Ghrelin enhances appetite and increases food intake in humans. J Clin Endocrinol Metab 86, 5992.

105. Neary NM, Small CJ, Wren AM, Lee JL, Druce MR, Palmieri C, Frost GS, Ghatei MA, Coombes RC \& Bloom SR (2004) Ghrelin increases energy intake in cancer patients with impaired appetite: acute, randomized, placebo-controlled trial. J Clin Endocrinol Metab 89, 2832-2836.

106. Druce MR, Wren AM, Park AJ, Milton JE, Patterson M, Frost G, Ghatei MA, Small C \& Bloom SR (2005) Ghrelin increases food intake in obese as well as lean subjects. Int $J$ Obes (Lond) 29, 1130-1136.

107. Laferrere B, Abraham C, Russell CD \& Bowers CY (2005) Growth hormone releasing peptide-2 (GHRP-2), like ghrelin, increases food intake in healthy men. $J$ Clin Endocrinol Metab 90, 611-614.

108. Schmid DA, Held K, Ising M, Uhr M, Weikel JC \& Steiger A (2005) Ghrelin stimulates appetite, imagination of food, $\mathrm{GH}, \mathrm{ACTH}$, and cortisol, but does not affect leptin in normal controls. Neuropsychopharmacology 30, 1187-1192.

109. Wynne K, Giannitsopoulou K, Small CJ, Patterson M, Frost G, Ghatei MA, Brown EA, Bloom SR \& Choi P (2005) Subcutaneous ghrelin enhances acute food intake in malnourished patients who receive maintenance peritoneal dialysis: a randomized, placebo-controlled trial. J Am Soc Nephrol 16, 2111-2118.

110. Ogden CL, Carroll MD, Curtin LR, McDowell MA, Tabak CJ \& Flegal KM (2006) Prevalence of overweight and obesity in the United States, 1999-2004. JAMA 295, $1549-1555$

111. Schussler P, Uhr M, Ising M, Weikel JC, Schmid DA, Held K, Mathias S \& Steiger A (2006) Nocturnal ghrelin, ACTH, $\mathrm{GH}$ and cortisol secretion after sleep deprivation in humans. Psychoneuroendocrinology 31, 915-923.

112. Weikel JC, Wichniak A, Ising M, Brunner H, Friess E, Held K, Mathias S, Schmid DA, Uhr M \& Steiger A (2003) Ghrelin promotes slow-wave sleep in humans. Am J Physiol Endocrinol Metab 284, E407-E415. 
113. Naitoh P (1976) Sleep deprivation in human subjects: a reappraisal. Waking Sleeping 1, 53-60.

114. Lennernas MAC, Akersted T, Hagman U, Bruce A \& Hambraeus L (1993) A new approach for evaluation of meal quality and meal patterns. J Hum Nutr Dietetics 6, 261-273.

115. Armstrong S (1980) A chronometric approach to the study of feeding behaviour. Neurosci Biobehav Rev 4, 27-53.

116. Adams CE \& Morgan KJ (1981) Periodicity of eating: implications for human food consumption. Nutr Res 1, $525-550$.

117. Verboeket-van de Venne WP \& Westerterp KR (1991) Influence of the feeding frequency on nutrient utilization in man: consequences for energy metabolism. Eur J Clin Nutr 45, 161-169.

118. Moore JG (1992) Chronobiology of the gastrointestinal system. In Biological Rhythms in Clinical and Laboratory Medicine, pp. 410-417 [Y Touitou and E Haus, editors]. Berlin: Springer-Verlag.

119. Sudo N \& Ohtsuka R (2001) Nutrient intake among female shift workers in a computer factory in Japan. Int J Food Sci Nutr 52, 367-378.

120. Vgontzas AN, Bixler EO \& Chrousos GP (2006) Obesityrelated sleepiness and fatigue: the role of the stress system and cytokines. Ann N Y Acad Sci 1083, 329-344.

121. Taheri S (2006) The link between short sleep duration and obesity: we should recommend more sleep to prevent obesity. Arch Dis Child 91, 881-884.

122. Van Cauter E, Polonsky KS \& Scheen AJ (1997) Roles of circadian rhythmicity and sleep in human glucose regulation. Endocrine Rev 18, 716-738.

123. Tiemeier H, Pelzer E, Jonck L, Moller HJ \& Rao ML (2002) Plasma catecholamines and selective slow wave sleep deprivation. Neuropsychobiology 45, 81-86.

124. Mander B, Colecchia E, Spiegel K, Kim R, Sannar E \& Van Cauter E (2001) Short sleep: a risk factor for insulin resistance and obesity. Diabetes 50, Suppl. 2, A45.

125. Mikuni E, Ohoshi T, Hayashi K \& Miyamura K (1983) Glucose intolerance in an employed population. Tohoku J Exp Med 141, Suppl., 251-256.

126. Simon C, Brandenberger G \& Follenius M (1987) Ultradian oscillations of plasma glucose, insulin, and C-peptide in man during continuous enteral nutrition. J Clin Endocrinol Metab 64, 669-674.

127. Van Cauter E, Desir D, Decoster C, Fery F \& Balasse EO (1989) Nocturnal decrease in glucose tolerance during constant glucose infusion. J Clin Endocrinol Metab 69, 604-611.

128. Simon C, Brandenberger G, Saini J, Ehrhart J \& Follenius M (1994) Slow oscillations of plasma glucose and insulin secretion rate are amplified during sleep in humans under continuous enteral nutrition. Sleep 17, 333-338.

129. Carroll KF \& Nestel PJ (1973) Diurnal variation in glucose tolerance and in insulin secretion in man. Diabetes 22, $333-348$.

130. Jarrett RJ (1979) Rhythms in insulin and glucose. In Endocrine Rhythms, pp. 247-258 [DT Krieger, editor]. New York: Raven Press.

131. Service FJ, Hall LD, Westland RE, O'Brien PC, Go VL, Haymond MW \& Rizza RA (1983) Effects of size, time of day and sequence of meal ingestion on carbohydrate tolerance in normal subjects. Diabetologia 25, 316-321.

132. Lee A, Agajanian T \& Bray GA (1985) Diurnal variation of insulin sensitivity exists in normal subjects but not in obese subjects. Diabetes 34, 125A.

133. Verrillo A, De Teresa A, Martino C, Di Chiara G, Pinto M, Verrillo L, Torello F \& Gattoni A (1989) Differential roles of splanchnic and peripheral tissues in determining diurnal fluctuation of glucose tolerance. Am J Physiol 257, E459-E465.

134. Boyle PJ, Scott JC, Krentz AJ, Nagy RJ, Comstock E \& Hoffman C (1994) Diminished brain glucose metabolism is a significant determinant for falling rates of systemic glucose utilization during sleep in normal humans. J Clin Invest 93, 529-535.

135. Moller N, Jorgensen JO, Schmitz O, Moller J, Christiansen J, Alberti KG \& Orskov H (1990) Effects of a growth hormone pulse on total and forearm substrate fluxes in humans. Am J Physiol 258, E86-E91.

136. Scheen AJ, Byrne MM, Plat L, Leproult R \& Van Cauter E (1996) Relationships between sleep quality and glucose regulation in normal humans. Am $J$ Physiol 271, E261-E270.

137. Buchsbaum MS, Gillin JC, Wu J, Hazlett E, Sicotte N, Dupont RM \& Bunney WE Jr (1989) Regional cerebral glucose metabolic rate in human sleep assessed by positron emission tomography. Life Sci 45, 1349-1356.

138. Maquet P, Dive D, Salmon E, Sadzot B, Franco G, Poirrier R, von Frenckell R \& Franck G (1990) Cerebral glucose utilization during sleep-wake cycle in man determined by positron emission tomography and $\left[{ }^{18} \mathrm{~F}\right] 2$-fluoro-2-deoxyD-glucose method. Brain Res 513, 136-143.

139. Maquet P, Dive D, Salmon E, Sadzot B, Franco G, Poirrier R \& Franck G (1992) Cerebral glucose utilization during stage 2 sleep in man. Brain Res 571, 149-153.

140. Maquet P (1997) Positron emission tomography studies of sleep and sleep disorders. J Neurol 244, Suppl. 1, S23-S28.

141. Plat L, Byrne MM, Sturis J, Polonsky KS, Mockel J, Fery F \& Van Cauter E (1996) Effects of morning cortisol elevation on insulin secretion and glucose regulation in humans. Am J Physiol 270, E36-E42.

142. Suwazono Y, Sakata K, Okubo Y, Harada H, Oishi M, Kobayashi E, Uetani M, Kido T \& Nogawa K (2006) Longterm longitudinal study on the relationship between alternating shift work and the onset of diabetes mellitus in male Japanese workers. J Occup Environ Med 48, 455-461.

143. Morikawa Y, Nakagawa H, Miura K, Soyama Y, Ishizaki M, Kido T, Naruse Y, Suwazono Y \& Nogawa K (2005) Shift work and the risk of diabetes mellitus among Japanese male factory workers. Scand J Work Environ Health 31, $179-183$.

144. Trenell MI, Marshall NS \& Rogers NL (2007) Sleep and metabolic control: waking to a problem? Clin Exp Pharmacol Physiol 34, 1-9.

145. Yaggi HK, Araujo AB \& McKinlay JB (2006) Sleep duration as a risk factor for the development of type 2 diabetes. Diabetes Care 29, 657-661.

146. Harsch IA, Schahin SP, Bruckner K, Radespiel-Troger M, Fuchs FS, Hahn EG, Konturek PC, Lohmann T \& Ficker JH (2004) The effect of continuous positive airway pressure treatment on insulin sensitivity in patients with obstructive sleep apnoea syndrome and type 2 diabetes. Respiration $\mathbf{7 1}$, 252-259.

147. Punjabi NM, Shahar E, Redline S, Gottlieb DJ, Givelber R \& Resnick HE (2004) Sleep-disordered breathing, glucose intolerance, and insulin resistance: The Sleep Heart Health Study. Am J Epidemiol 160, 521-530.

148. Grunstein RR, Stenlof K, Hedner J \& Sjostrom L (1995) Impact of obstructive sleep apnea and sleepiness on metabolic and cardiovascular risk factors in the Swedish Obese Subjects (SOS) Study. Int J Obes Relat Metab Disord 19, 410-418.

149. Kiely JL \& McNicholas WT (2000) Cardiovascular risk factors in patients with obstructive sleep apnoea syndrome. Eur Respir J 16, 128-133. 
150. Nieto FJ, Young TB, Lind BK, Shahar E, Samet JM, Redline S, D'Agostino RB, Newman AB, Lebowitz MD \& Pickering TG (2000) Association of sleep-disordered breathing, sleep apnea, and hypertension in a large community-based study. Sleep Heart Health Study. JAMA 283, 1829-1836.

151. Sookoian S, Gemma C, Fernandez Gianotti T, Burgueno A, Alvarez A, Gonzalez CD \& Pirola CJ (2007) Effects of rotating shift work on biomarkers of metabolic syndrome and inflammation. J Intern Med 261, 285-292.

152. van Coevorden A, Mockel J, Laurent E, Kerkhofs M, L'Hermite-Baleriaux M, Decoster C, Neve P \& Van Cauter E (1991) Neuroendocrine rhythms and sleep in aging men. Am J Physiol 260, E651-E661.

153. Kern W, Dodt C, Born J \& Fehm HL (1996) Changes in cortisol and growth hormone secretion during nocturnal sleep in the course of aging. J Gerontol A Biol Sci Med Sci 51, M3-M9.

154. Van Cauter E, Leproult R \& Kupfer DJ (1996) Effects of gender and age on the levels and circadian rhythmicity of plasma cortisol. J Clin Endocrinol Metab 81, 2468-2473.

155. Leproult R, Copinschi G, Buxton O \& Van Cauter E (1997) Sleep loss results in an elevation of cortisol levels the next evening. Sleep 20, 865-870.

156. Plat L, Leproult R, L'Hermite-Baleriaux M, Fery F, Mockel J, Polonsky KS \& Van Cauter E (1999) Metabolic effects of short-term elevations of plasma cortisol are more pronounced in the evening than in the morning. $J$ Clin Endocrinol Metab 84, 3082-3092.

157. Billaudel B \& Sutter BC (1979) Direct effect of corticosterone upon insulin secretion studied by three different techniques. Horm Metab Reg 11, 555-560.

158. Barseghian G \& Levine R (1980) Effect of corticosterone on insulin and glucagon secretion by the isolated perfused rat pancreas. Endocrinology 106, 547-552.

159. Pierluissi J, Navas FO \& Ashcroft SJ (1986) Effect of adrenal steroids on insulin release from cultured rat islets of Langerhans. Diabetologia 29, 119-121.

160. Khan A, Ostenson CG, Berggren PO \& Efendic S (1992) Glucocorticoid increases glucose cycling and inhibits insulin release in pancreatic islets of ob/ob mice. Am J Physiol 263, E663-E666.

161. Philippe J, Giordano E, Gjinovci A \& Meda P (1992) Cyclic adenosine monophosphate prevents the glucocorticoidmediated inhibition of insulin gene expression in rodent islet cells. J Clin Invest 90, 2228-2233.

162. Lambillotte C, Gilon P \& Henquin JC (1997) Direct glucocorticoid inhibition of insulin secretion. An in vitro study of dexamethasone effects in mouse islets. $J$ Clin Invest 99, 414-423.

163. Kalhan SC \& Adam PA (1975) Inhibitory effect of prednisone on insulin secretion in man: model for duplication of blood glucose concentration. J Clin Endocrinol Metab 41, 600-610.

164. Longano CA \& Fletcher HP (1983) Insulin release after acute hydrocortisone treatment in mice. Metabolism 32, 603-608.

165. Dinneen S, Alzaid A, Miles J \& Rizza R (1993) Metabolic effects of the nocturnal rise in cortisol on carbohydrate metabolism in normal humans. J Clin Invest 92, 2283-2290.

166. Boden G, Ruiz J, Urbain JL \& Chen X (1996) Evidence for a circadian rhythm of insulin secretion. Am J Physiol 271, E246-E252.

167. Takahashi Y, Kipnis DM \& Daughaday WH (1968) Growth hormone secretion during sleep. J Clin Invest 47, 2079-2090.
168. Honda Y, Takahashi K, Takahashi S, Azumi K, Irie M, Sakuma M, Tsushima T \& Shizume K (1969) Growth hormone secretion during nocturnal sleep in normal subjects. J Clin Endocrinol Metab 29, 20-29.

169. Sassin JF, Parker DC, Mace JW, Gotlin RW, Johnson LC \& Rossman LG (1969) Human growth hormone release: relation to slow-wave sleep and sleep-walking cycles. Science 165, 513-515.

170. Van Cauter E, Plat L \& Copinschi G (1998) Interrelations between sleep and the somatotropic axis. Sleep 21, 553-566.

171. Holl RW, Hartman ML, Veldhuis JD, Taylor WM \& Thorner MO (1991) Thirty-second sampling of plasma growth hormone in man: correlation with sleep stages. J Clin Endocrinol Metab 72, 854-861.

172. Van Cauter E, Kerkhofs M, Caufriez A, Van Onderbergen A, Thorner MO \& Copinschi G (1992) A quantitative estimation of growth hormone secretion in normal man: reproducibility and relation to sleep and time of day. J Clin Endocrinol Metab 74, 1441-1450.

173. Gronfier C, Luthringer R, Follenius M, Schaltenbrand N, Macher JP, Muzet A \& Brandenberger G (1996) A quantitative evaluation of the relationships between growth hormone secretion and delta wave electroencephalographic activity during normal sleep and after enrichment in delta waves. Sleep 19, 817-824.

174. Spiegel K, Leproult R, Colecchia EF, L'Hermite-Baleriaux M, Nie Z, Copinschi G \& Van Cauter E (2000) Adaptation of the 24-h growth hormone profile to a state of sleep debt. Am J Physiol Regul Integr Comp Physiol 279, R874-R883.

175. Moller N, Butler PC, Antsiferov MA \& Alberti KGMM (1989) Effects of growth hormone on insulin sensitivity and forearm metabolism in normal man. Diabetologia 32, 105-110.

176. Hampton SM (1983) The C-peptide of proinsulin: its diagnostic use and a possible physiological role. $\mathrm{PhD}$ Thesis, University of Surrey.

177. Morgan L, Hampton S, Gibbs M \& Arendt J (2003) Circadian aspects of postprandial metabolism. Chronobiol Int 20, 795-808.

178. Hampton SM, Morgan LM, Lawrence N, Anastasiadou T, Norris F, Deacon S, Ribeiro D \& Arendt J (1996) Postprandial hormone and metabolic responses in simulated shift work. J Endocrinol 151, 259-267.

179. Lasfargues G, Vol S, Caces E, Le Clesiau H, Lecomte P \& Tichet J (1996) Relations among night work, dietary habits, biological measure, and health status. Int J Behav Med 3, $123-134$.

180. Knutsson A \& Boggild H (2000) Shiftwork and cardiovascular disease: review of disease mechanisms. Rev Environ Health 15, 359-372.

181. Weibel L \& Brandenberger G (1998) Disturbances in hormonal profiles of night workers during their usual sleep and work times. J Biol Rhythms 13, 202-208.

182. Eckel RH (1989) Lipoprotein lipase. A multifunctional enzyme relevant to common metabolic diseases. $N$ Engl $J$ Med 320, 1060-1068.

183. Large V, Arner P, Reynisdottir S, Grober J, Van Harmelen V, Holm C \& Langin D (1998) Hormone-sensitive lipase expression and activity in relation to lipolysis in human fat cells. J Lipid Res 39, 1688-1695.

184. Patten RL (1970) The reciprocal regulation of lipoprotein lipase activity and hormone-sensitive lipase activity in rat adipocytes. J Biol Chem 245, 5577-5584.

185. Parker TS, McNamara DJ, Brown C, Garrigan O, Kolb R, Batwin H \& Ahrens EH Jr (1982) Mevalonic acid in human 
plasma: relationship of concentration and circadian rhythm to cholesterol synthesis rates in man. Proc Natl Acad Sci USA 79, 3037-3041.

186. Large V \& Arner P (1998) Regulation of lipolysis in humans. Pathophysiological modulation in obesity, diabetes, and hyperlipidaemia. Diabetes Metab 24, 409-418.

187. Corpas E, Harman SM \& Blackman MR (1993) Human growth hormone and human aging. Endocrine Rev 14, 20-39.

188. Angelin B \& Rudling M (1994) Growth hormone and hepatic lipoprotein metabolism. Curr Opin Lipidol 5, $160-165$.

189. Davidson MB (1987) Effect of growth hormone on carbohydrate and lipid metabolism. Endocrine Rev 8, $115-131$

190. Lind S, Rudling M, Ericsson S, Olivecrona H, Eriksson M, Borgstrom B, Eggertsen G, Berglund L \& Angelin B (2004) Growth hormone induces low-density lipoprotein clearance but not bile acid synthesis in humans. Arterioscler Thromb Vasc Biol 24, 349-356.

191. Macgorman LR, Consoli A, Jensen MD \& Miles JM (1987) Importance of growth hormone in the maintenance of basal lipolysis in normal man. Diabetes 36, 80A.

192. Tanaka K, Nicholson WE \& Orth DN (1978) Diurnal rhythm and disappearance half-time of endogenous plasma immunoreactive $\beta$-MSH (LPH) and ACTH in man. $J$ Clin Endocrinol Metab 46, 883-890.

193. Rantz AG (1978) Prolactin. N Engl J Med 298, 201-207.

194. White JE \& Engel FL (1958) Lipolytic action of corticotropin on rat adipose tissue in vitro. J Clin Invest 37, 1556-1563.

195. Winkler B, Rathgeb I, Steele R \& Altszuler N (1971) Effect of ovine prolactin administration on free fatty acid metabolism in the normal dog. Endocrinology 88, 1349-1352.

196. Rivera-Coll A, Fuentes-Arderiu X \& Diez-Noguera A (1994) Circadian rhythmic variations in serum concentrations of clinically important lipids. Clin Chem 40, 1549-1553.

197. Morgan L, Arendt J, Owens D, Folkard S, Hampton S, Deacon S, English J, Ribeiro D \& Taylor K (1998) Effects of the endogenous clock and sleep time on melatonin, insulin, glucose and lipid metabolism. J Endocrinol 157, 443-451.

198. Arasaradnam MP, Morgan L, Wright J \& Gama R (2002) Diurnal variation in lipoprotein lipase activity. Ann Clin Biochem 39, 136-139.

199. Romon M, Le Fur C, Lebel P, Edme JL, Fruchart JC \& Dallongeville J (1997) Circadian variation of postprandial lipemia. Am J Clin Nutr 65, 934-940.

200. Garrido E (2001) Análogos de insulina (Insulin analogues). An Fac Med Lima 62, 135-150.

201. Lemberger T, Saladin R, Vazquez M, Assimacopoulos F, Staels B, Desvergne B, Wahli W \& Auwerx J (1996) Expression of the peroxisome proliferator-activated receptor $\alpha$ gene is stimulated by stress and follows a diurnal rhythm. J Biol Chem 271, 1764-1769.

202. Cohen JC, Vega GL \& Grundy SM (1999) Hepatic lipase: new insights from genetic and metabolic studies. Curr Opin Lipidol 10, 259-267.

203. Connelly PW (1999) The role of hepatic lipase in lipoprotein metabolism. Clin Chim Acta 286, 243-255.

204. Jansen H, Breedveld B \& Schoonderwoerd K (1998) Role of lipoprotein lipases in postprandial lipid metabolism. Atherosclerosis 141, Suppl. 1, S31-S34.

205. Ribeiro DC, Hampton SM, Morgan L, Deacon S \& Arendt J (1998) Altered postprandial hormone and metabolic responses in a simulated shift work environment. $J$ Endocrinol 158, 305-310.

206. Ribeiro DCO, Hampton SM, Morgan L \& Arendt J (1999) Inappropriate nocturnal postprandial responses amongst shift workers. Proc Nutr Soc 58, 34A.

207. Cohn JS, McNamara JR, Krasinski SD, Russell RM \& Schaefer EJ (1989) Role of triglyceride-rich lipoproteins from the liver and intestine in the etiology of postprandial peaks in plasma triglyceride concentration. Metabolism 38, 484-490.

208. Lund J, Arendt J, Hampton SM, English J \& Morgan LM (2001) Postprandial hormone and metabolic responses amongst shift workers in Antarctica. J Endocrinol 171, 557-564.

209. Knapper JME, Puddicombe SM \& Morgan LM (1995) Enteroinsular hormones glucose-dependent insulinotropic polypeptide and glucagon-like peptide-1 (7-36) amide; effects on lipoprotein lipase activity in explants of rat adipose tissue. J Nutr 125, 183-188.

210. Anonymous (1993) NIH Consensus Conference. Triglyceride, high-density lipoprotein, and coronary heart disease. NIH Consensus Development Panel on Triglyceride, HighDensity Lipoprotein, and Coronary Heart Disease. JAMA 269, 505-510.

211. Hokanson JE \& Austin MA (1996) Plasma triglyceride level is a risk factor for cardiovascular disease independent of high-density lipoprotein cholesterol level: a meta-analysis of population-based prospective studies. $J$ Cardiovasc Risk 3, 213-219.

212. Jones PJ \& Schoeller DA (1990) Evidence for diurnal periodicity in human cholesterol synthesis. J Lipid Res 31, 667-673.

213. Miettinen TA (1982) Diurnal variation of cholesterol precursors squalene and methyl sterols in human plasma lipoproteins. J Lipid Res 23, 466-473.

214. Jones PJ, Leitch CA \& Pederson RA (1993) Meal-frequency effects on plasma hormone concentrations and cholesterol synthesis in humans. Am J Clin Nutr 57, 868-874.

215. Dietschy JM \& Wilson JD (1970) Regulation of cholesterol metabolism. N Engl J Med 282, 1128-1138; 1179-1183; $1241-1249$.

216. Popjak G, Boehm G, Parker TS, Edmond J, Edwards PA \& Fogelman AM (1979) Determination of mevalonate in blood plasma in man and rat. Mevalonate "tolerance" tests in man. J Lipid Res 20, 716-728.

217. Parker TS, McNamara DJ, Brown CD, Kolb R, Ahrens EH Jr, Alberts AW, Tobert J, Chen J \& De Schepper PJ (1984) Plasma mevalonate as a measure of cholesterol synthesis in man. J Clin Invest 74, 795-804.

218. McNamara DJ, Ahrens EH Jr, Parker TS \& Morrissey K (1985) Role of the kidneys in the metabolism of plasma mevalonate. Studies in humans and in rhesus monkeys. $J$ Clin Invest 76, 31-39.

219. Vondra K, Brodan V, Dobiasova M, Vitek V \& Kopecka J (1986) Effect of sleep deprivation on cholesterol metabolism and triglyceridaemia in male volunteers. Eur J Appl Physiol Occup Physiol 55, 83-87.

220. Cella LK, Van Cauter E \& Schoeller DA (1995) Diurnal rhythmicity of human cholesterol synthesis: normal pattern and adaptation to simulated "jet lag". Am J Physiol 269, E489-E498

221. Boyle PJ, Avogaro A, Smith L, Bier DM, Pappu AS, Illingworth DR \& Cryer PE (1992) Role of GH in regulating nocturnal rates of lipolysis and plasma mevalonate levels in normal and diabetic humans. Am J Physiol 263, E168-E172.

222. Parker DC, Rossman LG, Pekary AE \& Hershman JM (1987) Effect of 64-hour sleep deprivation on the circadian 
waveform of thyrotropin (TSH): further evidence of sleeprelated inhibition of TSH release. J Clin Endocrinol Metab 64, 157-161.

223. Brabant G, Prank K, Ranft U, Schuermeyer T, Wagner TO, Hauser H, Kummer B, Feistner H, Hesch RD \& von zur Muhlen A (1990) Physiological regulation of circadian and pulsatile thyrotropin secretion in normal man and woman. $J$ Clin Endocrinol Metab 70, 403-409.

224. Allan JS \& Czeisler CA (1994) Persistence of the circadian thyrotropin rhythm under constant conditions and after light-induced shifts of circadian phase. J Clin Endocrinol Metab 79, 508-512.

225. Van Cauter E \& Turek FW (1994) Endocrine and other biological rhythms. In Endocrinology, pp. 2487-2548 [LJ DeGroot, editor]. Philadelphia, PA: Saunders.
226. Guder W, Nolte I \& Wieland O (1968) The influence of thyroid hormones on $\beta$-hydroxy- $\beta$-methylglutarylcoenzyme A reductase of rat liver. Eur J Biochem 4, 273-278.

227. Ness GC, Dugan RE, Lakshmanan MR, Nepokroeff CM \& Porter JW (1973) Stimulation of hepatic $\beta$-hydroxy- $\beta$ methylglutaryl coenzyme A reductase activity in hypophysectomized rats by l-triiodothyronine. Proc Natl Acad Sci USA 70, 3839-3842.

228. van Amelsvoort LG, Schouten EG \& Kok FJ (2004) Impact of one year of shift work on cardiovascular disease risk factors. J Occup Environ Med 46, 699-706.

229. Gale SM, Castracane VD \& Mantzoros CS (2004) Energy homeostasis, obesity and eating disorders: recent advances in endocrinology. J Nutr 134, 295-298. 